\title{
The Effects of Camp Adventure Programs on Improving Self-concept of Youth Participants in Hong Kong 香港營地歷奇活動對青少年自我觀念的影響
}

\author{
Eric Wing-kin WONG Lobo Hung-tak LOUIE \\ Department of Physical Education, \\ Hong Kong Baptist University, HONG KONG
}

黄永堅雷雄德

香港浸會大學體育學系

\begin{abstract}
The purpose of the study was to identify the effects of camp adventure programs on improving the self-concept of youth participants with a view to providing management reference to enhance the value, quality and quantity of camp services in Hong Kong. A total of 339 respondents, aged from 12 to 25, answered the questionnaires. A thorough discussion has been made in accordance with the present findings on the following aspects: (a) the effects of camp adventure programs on improving different domains of self-concept of youth participants; and (b) to explore any possible factors and components that might contribute to the identified effects.
\end{abstract}

\section{摘 要}

本文旨在探討本港營地歷奇活動對改善青少年自我觀念的影響, 並從管理學層面提供建設性意見, 盼望能豿提升營舍服務的質素 及價值。共有 339 名年齡 12 至 25 歲回答了問卷，本文給予讀者詳細的討論，包括如何改善青少年自我觀念及其相關之因素。

\section{Introduction}

Adventure-based programs organized for recreational, educational and therapeutic use in schools, community centers, camps and corporate setting are getting more popular in Hong Kong. Adventure-based types of activities become a major part of almost all camping programs for the purposes of youth training.

Camping, as suggested by American Camp Association, was a sustained experience which provides a creative, recreational and educational opportunity in group living in the out-ofdoors. It utilized trained leadership and the resources of the natural surroundings to contribute to each camper's mental, physical, social, and spiritual growth.
Abundance of affirmative researches and evaluation findings supported that adventure education programs and outdoor experiential programs have the great potentials to enact change in participants and groups among a variety of populations and a number of environmental settings over the world (e.g. Cross, 2002; Garst, Scheider \& Baker, 2001; Hattie et al, Richards, 1997; Holman, 2003; Gass, Garvey \& Sugerman, 2003; McKenzie, 2003; Russell, 2000; Sibthorp, 2003). These research findings included an increase in self-esteem, selfefficacy, trust and group cohesion through adventure education programs. Given the variety of nearby natural resources and facilities suitable for conducting adventure programs in camps both for educational and recreational, adventure programs for teenagers and youths may be the way ahead of camps, especially non-government camps, locally. In Hong Kong, although there is a decline in the student enrollment in schools due to a 
recent low birth rate, youths still needs to break the cycles of failure that leads to negative self-concept, and bring about an increase in a person's ability to feel good about himself/ herself via well designed adventures activities.

Camping has unique components that, when properly administered, can improve the quality of life for campers (Shivers, 1989). A well-conducted camp is able to provide the educational, social, and recreational experiences vital to the growth and development of campers. It is no doubt that the content of a camping program is the main reason for young people to take part. As such, in order to meet the need of our changing society, in $21^{\text {st }}$ century, providing camp adventure programs with high quality is of great consequence.

Adventure activities are those outdoor pursuits that, in addition to being based upon the interrelationship of the human with the natural environment, apply stress to or challenge the participants purposefully (Ford \& Blanchard, 1993). A program is an elastic concept used to describe a variety of different operations, including activities, events, or services conducted by leisure service organizations (Rossman \& Schlatter, 2000). It can refer to a single activity, a collection of activities, a single event or a week-long sport festival. The key point is the notion of design, in which the programmer conceptualizes a leisure experience and intervenes in some way to facilitate it for the patron (Rossman \& Schatler, 2000).

In Western, the full list of activities used in adventure programming is rather long, such as : back-packing, canoeing, caving, climbing gyms, community service, desert trekking, kayaking, mountaineering, orienteering, rafting, raft sailing, rappelling, rock climbing, ropes courses, running, solos and others. The selection of camp activities may involve several factors including physical geography, native experience and expertise, and historical experience. However, owing to the unique geographical as well as easily-access locations of most camp sites in Hong Kong, modified adventure contents are often seen in Hong Kong.

According to Lee and Mak (2002), there are 13 camp sites in Hong Kong currently equipped with facilities suitable for adventure counseling programs. In Hong Kong, youth adventure programs are increasingly organized by camps, especially non-government camps, which charge their patrons at a higher price while comparing with their counterparts, Government camps, to boost up their usage nowadays. Although camp adventure programs are not a new product, it is worthwhile, if we want to improve the planning and management of relevant leisure services in camps, to check whether camp adventure programs for youth organized by camps in Hong Kong can really affect or even improve self-concept of youth participants as suggested by the research history all over the world and see what components and factors contributed to the effects, if any.

Self-concept is multidimensional notion and primarily involves cognitive processing. Hattie et al's self-concepts or conceptions of self were cognitive appraisals, expressed in terms of description, expectations, and/or prescriptions, integrated across various dimensions that we attributed to ourselves. Shavelson, Hubner, and Stanton (1976) placed salient values on these conceptions such that they were related in a hierarchical manner to form higher-order self-concepts. The lower-order dimensions can include achievement, ability and classroom self-concepts (which form a second-order dimension of academic self-concept), peer and family self-concepts (which form a social self-concept), and confidence and physical appearance self-concepts (which form a presentation selfconcept): Too often, studies in the adventure literatures have confused specific lower-order dimensions with higher-level concepts, and most have ignored the mechanisms used by participants to integrate the conceptions of self into higherorder notions. Therefore, Hattie et al's (1997) eleven subdomains of major outcome under categories of ìself-conceptî in adventure researches were used to represent the overall self-concept of respondents in the present study. A 7-point scale was then used to measure whether respondents agreed adventure programs have improved or enhance the domains of the self-concept.

The purpose of the study was to identify the effects of camp adventure programs on improving the self-concept of youth participants with a view to providing management reference to enhance the value, quality and quantity of camp services in Hong Kong. In addition, the following aspects would be explored: (a) to examine the effects of camp adventure programs on improving different domains of self-concept of youth participants; (b) to explore the factors and components that contribute to the effects. 


\section{Background}

The deliberate use of risk and danger under the caption of adventure had a rich and diverse history. Two additional areas of interest emerged related to adventure recreation by the 1940s. They were two separate but related pathways of the use of adventure activities for therapy and using adventure for educational purposes. The forerunner of these movements and the most widely recognized adventure-based program was Outward Bound. Much of the research literature could be categorized as adventure for recreation, therapeutic intent, or achieving educational purposes. The first two sections of the following discussion are mainly related to research on the adventure experience in terms of recreation purposes and educational purposes. Outcomes of adventure programs, with emphasis on change in self-concept, models of adventure process and adventure programs in camps would then be discussed.

\section{Adventure for Recreation}

Adventure recreation could be defined as recreational and/or educational activities utilizing a close interaction with the natural environment, that contain elements of real or perceived risk and danger, in which the outcome while uncertain, can be influenced by the participant and circumstance (Ewert, 1989). Under this definition, adventure recreation had most often been studied from the perspectives of the effects of risk on the participant, what recreational, therapeutic, or educational outcomes had been realized, levels and types of involvement in adventure recreation activities and how did participation in adventure programs impact the individual's self-concept.

Adventure recreation emphasizes the enjoyment and satisfaction derived from an activity. Benefits of adventure recreation could be divided into social and individual benefits; wilderness centered, activity oriented; therapeutic benefits, and professional issues (Attarian, 1991). Priest (1992) developed the Dimensions of an Adventure Experience (DAE) instrument to find perceived risk were related to fear, eustress, and distress while personal competence were related to abilities and attitudes. Priest and Carpenter (1993) further supported perception of risk and of personal competence change as a result of participation in adventurous activities by using the DAE. Analysis that perception of situational risks did decrease across subjects and perception of competence did increase with participation. Priest and Bunting (1993) found that participation in a threeday whitewater canoeing trip resulted in decreases in perceived risk, as well as increases in perceived competence. The greatest change occurred in terms of diminished fear and enhanced ability, while eustress, distress, and attitudes showed less change over the course.

Freischlag and Freischlag (1993) tested the flow paradigm (Csikszentmihalyi, 1977) with 102 rock climbers and found that more positive self-assessments as their ability to climb increased, which confirms the flow paradigm in this study. Other findings included for those individuals who achieved enduring levels of risk recreation involvement, the "expressive and processual nature of risk recreation tended to enhance psychological well-being" (Robinson, 1992); participant selfefficacy continued to increase as much as one year following their participation in adventure programs (Paxton, 1999); participants of ropes course generally sought positive selfimproving goals and benefits (Goldenberg et al, 2000).

\section{Adventure of Achieving Educational Purposes}

Most researchers traced the origin of modern and adventure education to Kurt Hahn (1957), who devised the first Outward Bound program for the Blue Funnel Shipping Line to reduce the loss of lives due to sinking of their ships in the Atlantic Ocean. The social and personal learning is the key value of adventure education.

The use of outdoor experiences for educational purposes had a rich history. Adventure-based programs are now used in schools, community programs, camps and corporate setting around the globe. Adventure education involves the purposeful planning and implementation of educational processes that involve risk in some way (Miles \& Priest cited in Hopkins \& Putnam, 1998). The risk may be physical, social or spiritual. The defining characteristic of adventure education is that a conscious and overt goal of the adventure is to expand the self, to learn and grow and progress toward the realization of human potential (Miles \& Priest cited in Hopkins \& Putnam, 1998). The learning about the self and the world that come from engagement in adventure education programs are the primary goals (Miles \& Priest cited in Hopkins \& Putnam, 1998). Mortlock (cited in Hopkins \& Putnam (1998)) defined adventure as a state of mind that begins with feelings of uncertainty about the outcome of a journey and always ends with feelings of enjoyment, satisfaction, or elation about the successful completion of that journey. 
According to Hattie et al (1997), the common features of adventure programs were (a) wilderness or backcountry settings; (b) a small group (usually less than 16); (c) assignment of a variety of mentally and/or physically challenging objectives, such as mastering a river rapid or hiking to a specific point; (d) frequent and intense interactions that usually involve group problem solving and decision making; (e) a nonintrusive, trained leader; and (f) a duration of 2 to 4 weeks (p. 44).

Although the physical nature of the outdoor activities is a part of the program, physical fitness and physical skills are not the primary goals. Physical activities are used as an effective medium for participants to recognize and understand their own weaknesses, strengths, and resources and thus find the wherewithal to master the difficult and unfamiliar in other environments. The establishment and fulfillment of personal and group goals in outdoor physical activities, the group experience, and the opportunity to experience and master stressful situation are all important components of adventure programs in general.

During 1970s, there was a growing awareness that the impact of adventure programs was due to changes in the self-perceptions of the participants and to the way each person absorbed the experiences into his or her self-structure (Hattie et al, 1997). Enhancement of self-concept became the primary aim. The evidence was generally supportive (Ewert, 1983); however, the research ignored the advances that were being made at that time in self-concept theory and measurement (Shavelson, Hubner and Stanton, 1976) and thus tended to be simplistic. Adventure programs were variously described as forms of sensitivity training (Lewicki, 1977), simply a wilderness adventure movement (Lowenstein, 1975), a new form of "progressive education" (Nold, 1976), and part of the newly fashionable "experiential movement" (Leiweke, 1976). Anyway, early research was based mostly on simplistic homilies that, for instance, Outward Bound must be successful (Hahn, 1957); descriptions of the programs (Miner \& Boldt, 1981); testimonials from the converted (Wilson, 1981).

\section{Outcomes of Adventure Programs}

There had been an abundance of outcome measures used to evaluate adventure programs. For example, Ewert (1989) had identified the potential psychological benefits of outdoor adventure recreation as being: Self-concept, Confidence, Selfefficacy, Sensation-seeking, Actualization, Well-Being, and Personal Testing. However, according to Hattie et al (1997), most researches on the adventure experience had tended to use either single outcome measures or omnibus measures, with all outcomes regarded as equally important. It may be only parts of the adventure program and not necessarily the total experience that made the difference.

Scherl and Smithson (1986) demonstrated that changes to self-concept were primarily related to mental effort that invested in devising coping strategies. That is, $46 \%$ of the time that the category "effort" was used by participants, there was also a reference to self.

Cason and Gillis (1994) reported a meta-analysis of adventure programs for 11-years-old students to college freshmen. They included 147 effects based on 43 studies from throughout the world and found an average effect size of .31. The effects and most outcomes were high: self-concept (.34), behavioral assessments by others (.40), locus of control (.30), grades (.61), and school attendance (.47). The only program effect they identified as moderating their conclusion was length of program: Longer programs had higher effects (.58) than medium (.19) and short (.17) programs. There were no differences between various types of participants (e.g. adjudicated, inpatients, emotionally or physically challenged, and 'normal' adolescents), but effect sizes from higher-quality studies tended to be greater than those from lower-quality studies. Based on 151 unique samples, Hattie et al identified 40 major outcomes in the adventure literatures, which could be placed into 6 more encompassing categories: leadership, self-concept, academic, personality, interpersonal, and adventuresomeness. Subdomains and examples of the major outcome under categories of "self-concept" in adventure researches were listed in Figure 1. 


\section{Figure 1. Sub-domains and Examples of the Major Outcome under Categories of 'Self-Concept'}

\begin{tabular}{lll}
\hline Subdomains & Examples or other names \\
\hline 1. & Physical ability & \\
2. & Peer relations & Self peers, self-same sex, opposite sex self-concept \\
3. & General self & Self-values, self-general, self-esteem, self-concept \\
4. & Physical appearance & \\
5. Academic & Self-problem solving \\
6. & Confidence & Potency, emotional self \\
7. & Self-efficacy & Self-control, self-sufficient, self-reliance \\
8. & Family & Self-parents, self-home \\
9. & Self-understanding & Self-honesty, self-disclosure, self-criticism, self-awareness \\
10. & Well-being & Life success, satisfaction, positive endeavor \\
11. & Independence & Autonomy \\
\hline
\end{tabular}

Self-concept had been one of the major outcomes investigated for adventure programs. The greatest effects of the adventure programs in the self-concept domain were for independence, confidence, self-efficacy, and self-under standings, and they were further enhanced during follow-up periods (Hattie et al, 1997). They referred these domains as a higher-order domain of ìpresentation of selfî. The effects on many of the lowerorder dimensions (e.g., peers, family) were typically smaller but still high when compared to many other self-concept programs.

The self is a slippery and difficult concept. The self is not something ready made, but something in continuous formation through choice of actions (Deway cited in Hopkins \& Putnam, 1998). Self-concept is the way in which individuals perceive themselves in relation to the world around them (Rogers cited in Hopkins \& Putnam, 1998). Rogers further elaborated that the self comprises the characteristics which individuals believe are uniquely their own, and as such are the central component of their total experience. A growth in, or a more positive, self-concept may mean that there is evidence of a more coherent and realistic appreciation of one's individuality. In other words, the 'idea self' and the 'perceived self' are in closer proximity.

Parle (1986) and Matthai (1973) demonstrated that Outward Bound programs had positive effects on adolescents' confidence in themselves and their ability to act successfully in a variety of challenging situations. Enhancing self-control or independence might be the mediating effect to enhanced self-concept. Selfcontrol involved controlling the self so as to respond appropriately to environmental contingencies. The only effective way to do this was to develop and maintain self-control.
The effects of the adventure program on physical ability self-concept in Hattie et al's meta-analysis were low, though the effects on actual physical fitness were high. On followup, however, the effects on the physical ability self-concept measures were very high, and actual physical ability declines. Besides, there were no effects on physical ability self-concept even though there were gains in fitness and other health related benefits (Marsh \& Peart, 1988).

The major benefits for adventure programs were reasonably consistent across all six major categories of outcomes (Hattie et al, 1997). They agreed that a theme underlying the outcomes with the greatest effects related to self-control. These included independence, confidence, self-efficacy, self-understanding, assertiveness, internal locus and control, and decision making. These outcomes related to a sense of control over or regulation of the self, responsibility, or an assurance of self. Most of these effects were maintained over time. Thus, adventure programs appeared to be most effective at providing participants with a sense of self-regulation.

\section{Models of Adventure Process}

A cadre of philosophers and theoreticians such as Kiewa, Luckner and Nalder, Walsh \& Golins have offered models of adventure process. One of the largely accepted doctrines within the field is the model of ithe Outward Bound Processî put forward by Walsh and Golins in 1976. They have made a seminal contribution to thinking in this area and their papers should be compulsory reading for all those interested in the process of adventure education (Hopkins \& Putnam, 1998). The model includes a motivated learner or program participant 
being placed into a prescribed social and physical environment where he or she masters specific problem solving tasks. The course instructor acts as a guide to ensure that the tasks are both authentic and manageable and provides the necessary feedback to aid mastery, which, in turn, leads to participant development (e.g., an increase in self-esteem).

Hattie et al. (1997) found adventure programs had a diverse array of effects on self-concept, locus of control and leadership. Sibthorp (2003) and McKenzie (2003) recently addressed to this area with a view to understanding the interrelationships in depth. Indeed, they helped further clarify the means by which Walsh and Golins (1976) model are working.

Sibthorp (2003)'s study sought to determine if adventure program participants antecedent factors (examples include age, gender, expectations, motivations, past experience and preexisting beliefs), experience perceptions of characteristics of their experiences (examples include perception of social environment, level of instructor support) and changes in their self-efficacy are related. Sibthorp (2003) focused on three domains of self-efficacy directly related to the program goals: leadership, social functioning, and self-regulation. Throughout his study, the term adventure education was used to discuss experiential programs that used adventure to achieve educational or developmental goals. The samples were all of the 301 students that participated in Underwater Discoveries for now certified divers or Underwater Discoveries Advanced for certified divers programs of the Broadreach programs which include traditional adventure education processes such as full-value contracts, leadership responsibilities, and structured feedback and debriefings. The results of Sibthorp's (2003) analysis generally supported the Walsh and Golins (1976) model and the related literature and the theory of adventure education. However, the results of Sibthorp's (2003) analysis did not support that antecedent variables such as motivation were linked to developmental outcomes and more research was needed in this area (Hattie et al., 1997). Sibthorp (2003) further posited a direct relationship between the antecedent variables and changes in self-efficacy was not evident and it was likely that the program characteristics are acting as mediating variables between antecedents and developmental outcomes. In summary, antecedent factors and characteristics of the experience variables are central pieces of the adventure process puzzle, and increased awareness remains a potential program outcome needing more research attention (Sibthorp, 2003).
McKenzie's (2003) works were to extend our understanding beyond the insightful and popular model of ithe Outward Bound Processî put forward by Walsh and Golins in 1976 and look beyond current students' experiences to some possible influences modern society has had on Outward Bound courses. Data were collected from 92 Outward Bound Western Canada (OBWC) students between June and October of 1999 using a questionnaire, interviews, and researcher observation of group discussions. Twenty-eight aspects of "course components" emerged from the data as having an influence on course outcomes and can be placed in five groupings, with qualitative data. The categories of outcomes included "self-concept" (defined as including self confidence and self-reliance), "motivation" (defined as the desire to learn and achieve), and "interpersonal skills" (defined as including cooperation and communication). McKenzie (2003) found the course components which resulted in the greatest increases in students' self-confidence, self-reliance, self-esteem, and self-concept were the closely linked components of achieving individual success and challenge. Thus, the data were less conclusive with regard to the course components that led to increases in motivation. Course components that were found to have a direct, negative impact on students' self-concept, motivation, and interpersonal skills include failing to achieve success, the course-end run and working as a group. Females reported greater benefits from OBWC courses than males with the means for overall impact on self-concept, motivation, and interpersonal skills all significantly higher for females than for males. The data collected from females indicated statistically significant differences between age groups for the overall impact of course on self-concept, motivation, and interpersonal skills. In summary, course activities, the physical environment, instructors, the group, and students' characteristics were found to influence course outcomes. McKenzie (2003) further included "service" and ìcourse instructorsî in his alternative version of the ways through which learning takes place on Outward Bound courses and linked all course components more directly with reflection and learning.

\section{Adventure Programs in Camps}

Limited studies on the effects of camp adventure programs could be identified in Hong Kong, though quite a number of studies on adventure based counseling have been conducted here. According to the report on evaluation of the Understanding the Adolescent Project (UAP) in secondary school 2001/02, outdoor activities were reported to be the best received format of activities in the comprehensive primary preventive programme (PPP) supported by the education and manpower Bureau. A 3-day camp named "The Challengers' Camp" was one of its 
kings. Activities in "The Challengers' Camp" included 6 sessions of adventure tasks, i.e. trust-ladder, low-beam, zig-zag, spiderweb, low V, nitro-crossing, electric-fence, parachute, whalewatch, rock climbing, aiming at fostering resilience of the students to face life's challenge by improving their sense of competence, optimism and belongingness. The PPP (with the emphasis of adventure-based therapy) was found to have positive effort on students (identified with HKSIF positive) (UAP Evaluation Report).

Outcomes of organized camping in United States of America had been reviewed extensively by Barbara Delansky in the University of Oregon in agreement with the American Camping association in 1991. Some studies indicated a positive outcome on participants' self-concept whereas some studies failed to demonstrate significant changes in self-concept as a result of organized camp experiences.

The effect of organized camp experiences on participant self-concept emerged as major research area in the late 1960's in USA. Krieger (1970) (cited in Delansky, 1991) examined the effects of an organized camping experience on self-concept in relation to age and sex. No effect of camping on selfconcept as a result of age and sex was found. Wander (1973) (cited in Delansky, 1991) studied changes in self-concept in several organized residential camps. Self-concept scale was administrated to children in seven camps on the first and last day of camp. No significant differences were found in the degree of self-concept change between disadvantage and advantaged campers in both the one week and two week program. Dustin (1974) (cited in Delansky, 1991) examined the short term relationship between improvements in selected dimensions of self-concept and the reduction of stuttering severity as a result of residential camping experience. Results showed a significant reduction in stuttering severity. However, it did not support a positive relationship between reduction in stuttering severity and improved self-concept. Draper (1975) (cited in Delansky, 1991) assessed the effect of a one-week residential Boy Scout camping experience on the self-concept of adolescent males. The Piers Harris Self-concept Scale was offered to experimental group and control group during their regular troop meeting one week prior to the camp experience. Both groups showed some positive change in self-concept. Differences between the groups were not statistically significant and failed to demonstrate that the change in self-concept was due to camping.
Rubinstein (1977) (cited in Delansky, 1991) investigated the effects of a task-oriented, competitive camp program and an expressive, non-competitive camp program on campers' level of self-esteem and anxiety. The Rosenberg's Self-esteem Scale and the IPAT Youth Anxiety Scale were used to collect data. In both camps, those children who had the opportunity to enjoy interactions and engage in activities in which they were capable experienced an increase in self-esteem.

Chestnutt (1980) (cited in Delansky, 1991) examined the effects of a three week adventure oriented experience and a five week leadership experience on self-concepts on the self-concept of counselors-in-training by using the Pier Harris Self-concept Scale. Findings showed that the camp experience did not appear to have a positive effect on self-concept. Selfconcept seemed to be relatively stable and was independent of grade level, socio-economic status, school activity and previous camp experience.

Numerous studies concentrated on the effects of Outward Bound programs n USA specifically designed as delinquency interventions. Wright (1982) (cited in Delansky, 1991) explored the effects of high adventure activities on adolescent selfconcept. Instruments used to collect data included the Tennessee Self-concept Scale, the Gough Adjective Check List. Participants showed significant positive increases in nine out of ten scales of the Tennessee Self-concept Scale and 23 out of 24 items on the Gough Adjective Checklist List $(\mathrm{p}<0.5)$. Changes in self-concept were not significant related to differences in sex, age or previous adventure experience. Cowin (1988) (cited in Delansky, 1991) tried to identify factors that affected self-concept and psychological well-being in camp setting in USA. A pre and post test design was used. The Piers Harris Self-concept Scale was used on the first day, 54 days after camp and fifteen weeks after camp. Findings indicated that a significant, positive change in self-concept after 54 days and a significant reduction in self-concept from day 54 to fifteen weeks. Long lasting change of self-concept appeared to be marginal. Change in self-concept did not differ by status and age.

\section{Method}

\section{Measuring Instruments}

In Hong Kong, camps and organizations with adventure area and facilities organize various adventure programs of different length for different targets all year round. To ensure representative samples could be collected, all camps known 
to have organized adventure programs were invited by email to participate in the survey from the first of August to midSeptember 2005. After referring to the list of adventure programs and facilities currently provided in Hong Kong suggested by Lee and Mak (2002), and checking the latest camp information in the internet, email invitations were sent to 17 camps. Five camps agreed to support the survey. 357 questionnaires were finally collected from four camps as one camp eventually cannot identify suitable respondents during the survey period. A total of 339 respondents eventually fell within the study's target population, age ranged from 12 to 25 .

The questionnaire was a self-completion one. Respondents were requested to read the questions and put a tick in the appropriate boxes and fill in the blank as appropriate after completing their adventure program. A guideline was incorporated in the covering letter to camp management to request camp staff to provide necessary and essential guidance to respondents while they completed the questionnaires.

The questionnaire was divided into four parts. The first part of the questionnaire was to identify the length of respondents' adventure program. The second part of the questionnaire was to explore what types of activities were included in their adventure programs. Respondents were asked directly whether they agreed the adventure programs have improved/enhance eleven domains of their self-concepts as suggested by Hattie et al (1997). Self-problem solving, the only example of the ìAcademicî domain given by Hattie et al (1997), was used to replace ìAcademicî domain in the questionnaire because this domain was hard to be understood by respondents if direct translation was quoted. The eleven domains were physical ability, peer relationship, general self, physical appearance, self-problem solving, confidence, self-efficacy, family, selfunderstanding, well-being and independence. As three out of 11 domains of the self-concept, i.e. general self, self-efficacy and well-being, may also be difficult to be understood by respondents after being translated in Chinese, an example of other name from each of these domains as suggested by Hattie et al (1997) was added as a supplementary domain for cross- checking the validity of the domains. The total domains in the questionnaires were then come up to 14. A 7-point scale was used: 0 - no idea; 1 - strongly disagree; 2 - disagree; 3 - slight disagree; 4 - slight agree; 5 - agree; 6 - strongly agree. The fourth part consisted of questions asking the respondents whether they agreed that adventure programs changed them through the seven factors/components as suggested in the alternative model of student learning building on Walsh and Golins' (1976) Outward Bound process proposed by McKenzie (2003). A 7-point scale similar to the one used in the analysis of the impact of adventure programs was used. At the end of the questionnaire, respondents are invited to input their gender and age.

\section{Statistical Analysis}

Simple frequency distribution was used to analyze the respondent profile, length of adventure programs conducted and types of adventure programs included in these adventure programs. Effects on various domains of self-concept and importance of program components were thus analyzed. Correlations among different domains of self-concept and different components/factors of adventure process were calculated. A Factor Analysis on domains of self-concept with perceived change and on components/factors causing the change were conducted. Independent t-tests were used to compare the mean effects on self-concept and importance of program component, in terms of genders, ages and length of programs. All the statistical tests were set at $\mathrm{p}<0.05$ level.

\section{Resullts}

\section{Respondent Profille}

Questionnaires from a total of 357 (males $=41.5 \%$, females $=57.1 \%$, no response $=1.4 \%$ ) participants aged 11 to 53 from 4 camps (i.e. Breakthrough Youth Village, YWCA Wong Yi Chau Youth Camp, Jockey Club Sai Kung Outdoor Training Camp and HKPA Silvermine Bay Outdoor Recreation Centre) were received.

Table 1. Sources of Respondents.

\begin{tabular}{|c|c|c|}
\hline & Frequency & Valid Percent \\
\hline Breakthrough Youth Village & 137 & 40.4 \\
\hline YWCA Wong Yi Chau Camp & 64 & 18.9 \\
\hline HKFYG Outdoor Training Centre & 58 & 17.1 \\
\hline HKPA Silvermine Bay Outdoor Recreation Centre & 80 & 23.6 \\
\hline Total & 339 & 100.0 \\
\hline
\end{tabular}


Table 2. Gender of Respondents.

\begin{tabular}{|c|c|c|c|c|c|}
\hline & & & Frequency & Percent & Valid Percent \\
\hline \multirow[t]{3}{*}{ Valid } & Male & & 144 & 42.5 & 43.1 \\
\hline & Female & & 190 & 56.0 & 56.9 \\
\hline & & Total & 334 & 98.5 & 100.0 \\
\hline \multirow[t]{2}{*}{ Missing } & No Response & & 5 & 1.5 & \\
\hline & & Total & 339 & 100.0 & \\
\hline
\end{tabular}

The ages of camp adventure program participants ranged from 11 to 53. Of the total 357 respondents surveyed, 339 campers fall within my study's target population, i.e. youth participants aged 12 to 25 . Among 339 target population being surveyed, 144 (i.e. $42.5 \%$ ) were male participants and 190 (i.e. $56.0 \%$ ) were female participants whereas 5 participants failed to indicate their gender. Only $27.7 \%$ of respondents (i.e. 92 nos.) were aged 18 and over whereas nearly $72.3 \%$ of respondents were in the age range of 12 to 17 . The highest percentage of target population was at the age of 17 , which composed of $22.9 \%$ respondents of the total target population. Nearly half of the respondents (i.e. $48 \%$ ) were at the age of $12(16.0 \%), 16(10.2 \%)$ and $17(22.9 \%)$.

Table 3. Age of Respondents.

\begin{tabular}{lccc}
\hline & Age & Frequency & Valid Percent \\
\hline \multirow{2}{*}{ Valid } & 12 & 53 & 16.0 \\
& 13 & 28 & 8.4 \\
& 14 & 32 & 9.6 \\
& 15 & 17 & 5.1 \\
& 16 & 34 & 10.2 \\
& 17 & 76 & 22.9 \\
& 18 & 31 & 9.3 \\
& 19 & 12 & 3.6 \\
& 20 & 13 & 3.9 \\
& 21 & 9 & 2.7 \\
& 22 & 3 & .9 \\
& 23 & 5 & 1.5 \\
& & 4 & 1.2 \\
Missing & 24 & 15 & 4.5 \\
\hline & & 100.0 & \\
\hline & & & \\
\hline
\end{tabular}

\section{Length of Adventure Programs}

Of 339 respondents, 226 respondents (66.7\%) joined overnight adventure programs ranged from 2-day-1-night to 5-day-4-night. More than 50\% respondents joined 3-day-2night programs. $54.6 \%$ (185 out of 226) respondents joined overnight programs participated in the 3-day-2-night adventure programs whereas $10.9 \%$ (37 out of 226) respondents joined 4-day-3-night adventure programs. Only 2 respondents joined 2-day-1-night adventure programs and only 2 respondents joined 5-day-4-night adventure programs. 49 respondents (14.5\%) joined one-day camp program. 55 respondents $(16.2 \%)$ joined 1 to 3 hours adventure programs with single adventure activity. On the whole, it was no doubt that 3-day-2-night were the most popular program length in camps. 
Table 4. Length of Adventure Programs.

\begin{tabular}{|c|c|c|}
\hline & Frequency & Valid Percent \\
\hline 1 session ( $1-3$ hours $)$ & 55 & 16.2 \\
\hline 2 sessions (one day) & 49 & 14.5 \\
\hline 3 sessions ( 2 days 1 night) & 2 & 6 \\
\hline 6 sessions ( 3 days 2 nights) & 185 & 54.6 \\
\hline 9 sessions (4 days 3 nights) & 37 & 10.9 \\
\hline 12 sessions (5 days 4 nights) & 2 & .6 \\
\hline No Response & 9 & 2.7 \\
\hline Total & 339 & 100.0 \\
\hline
\end{tabular}

\section{Types of Adventure Activities}

Counseling and trust activities are the most widely used activities among other adventure activities in camp programs. 203 out of 339 respondents mentioned their adventure programs included counseling and trust activities. Various kinds of counseling \& trust activities were reported to be included in the respondents' adventure programs. Trolley (大腳板) (i.e. 38 respondents) was being the most quoted counseling \& trust activities among other quoted counseling \& trust activities such as Trust Ladder (信心天梯) and Spider Web (蜘蛛網). In other words, counseling \& trust activities were the core elements of the camp adventure programs in Hong Kong. Such activities were easily to be managed by camp staff and were comparatively less risky than other adventure activities. Among the rest of camp adventure activities, night walk was the highest chosen activity in camp adventure programs. 133 respondents reported that they had joined night walk activity. It was clear that nature environment of camp provided a good source for and fixed the possible content of camp adventure programs. Native experience and expertise in camps may be another factor. Sports climbing were reported to be the third widely used activity in camp adventure programs. 87 respondents reported that they had sport climbing activity. Camp facilities open for all campers for training and recreational purpose was another source for camp adventure programs. Hiking, high rope course and wild camp were fourth group of widely used adventure activities. 42 respondents reported that they had hiking activity, 35 respondents reported that they had high rope course activity and 30 respondents reported that they had wild camp activity. Furthermore, 10 respondents reported they had rope course activity and 18 respondents reported that they had beam activity. Unfortunately, only a few respondents reported that they had rock climbing (1 respondent), high wall (1 respondent), rafting (2 respondents), trust fall (3 respondents) and canoeing ( 1 respondent). Even though all listed adventure activities can be conducted strictly for recreation purpose, only respondents that were leaded by camp staff to participate in camp adventure programs with proper briefing and debriefing were invited to complete the self-completed questionnaires. Guidelines were also given to camp staff to remind respondents what types of adventure activities they had.

Table 5. Types of Activities in Adventure Programs.

\begin{tabular}{lc}
\hline Types of Activities & Frequency \\
\hline Rock Climbing & 1 \\
Sports Climbing & 87 \\
Hiking & 42 \\
Rope Course & 10 \\
High Rope Course & 35 \\
High Wall & 1 \\
Beam & 18 \\
Rafting & 2 \\
Night walk & 133 \\
Counseling Activities & 203 \\
Trust Fall & 3 \\
Wild Camp & 30 \\
Canoeing & 1 \\
Other Activities & 22 \\
\hline
\end{tabular}

\section{Effects on Different Domains of Self-concept}

Eleven questions were asked to obtain opinions from subjects on the effects of camp adventure programs on their self-concept. As discussed in the ìmeasuring instrumentsî session, due to the fact that three domains may be difficult to be understood by respondents, an example of these three domains, i.e. self esteem for general self, self-control for self-efficacy, satisfaction for well being, was added. As such, a total of fourteen questions or items were included in the questionnaire. 
The range of the answers used in calculation became 1 to 6 representing from "strongly disagree" to "strongly agree" respectively. A mean value of 3.5 would be the middle point of the range and any score higher than this point represented tendency towards the "more agreeable" and could be identified as a potential result of adventure programs perceived by respondents. Table 6 showed the corresponding values of mean and standard deviation of different domains.

Table 6. Means and Standard Deviations of Eleven Domains of Self-concept and Examples of Three Domains.

\begin{tabular}{|c|c|c|c|c|c|}
\hline \multicolumn{2}{|l|}{ Domains } & \multirow{2}{*}{$\begin{array}{l}\text { Count } \\
339\end{array}$} & \multirow{2}{*}{$\begin{array}{l}\text { Valid } \mathbf{N} \\
\mathrm{N}=339\end{array}$} & \multirow{2}{*}{$\begin{array}{l}\text { Mean } \\
3.71\end{array}$} & \multirow{2}{*}{$\begin{array}{l}\begin{array}{l}\text { Standard } \\
\text { Deviation }\end{array} \\
1.56\end{array}$} \\
\hline Domains Suggested & Physical Ability & & & & \\
\hline \multirow[t]{10}{*}{ by Hattie et al (1997) } & Peer Relationship & 339 & $\mathrm{~N}=338$ & 4.76 & 1.27 \\
\hline & General Self & 339 & $\mathrm{~N}=339$ & 3.93 & 1.55 \\
\hline & Physical Appearance & 339 & $\mathrm{~N}=338$ & 3.27 & 1.67 \\
\hline & Self-problem Solving & 339 & $\mathrm{~N}=335$ & 4.23 & 1.62 \\
\hline & Confidence & 339 & $\mathrm{~N}=338$ & 4.49 & 1.48 \\
\hline & Self-efficacy & 339 & $\mathrm{~N}=334$ & 4.07 & 1.64 \\
\hline & Family & 339 & $\mathrm{~N}=335$ & 2.81 & 1.88 \\
\hline & Self-understanding & 339 & $\mathrm{~N}=339$ & 4.29 & 1.53 \\
\hline & Well-being & 339 & $\mathrm{~N}=339$ & 4.29 & 1.57 \\
\hline & Independence & 339 & $\mathrm{~N}=339$ & 4.26 & 1.56 \\
\hline An example of Three & Self-esteem & 339 & $\mathrm{~N}=339$ & 4.06 & 1.65 \\
\hline Domains difficult to be & Self-control & 339 & $\mathrm{~N}=339$ & 4.06 & 1.71 \\
\hline understood & Satisfaction & 339 & $N=339$ & 4.66 & 1.59 \\
\hline
\end{tabular}

There were totally nine out of eleven original Hattie et al's domains scored with mean values higher than 3.5 and were classified as perceived valid domains by the respondents. The nine domains were physical ability, peer relationship, general self, self-problem solving, confidence, self-efficacy, selfunderstanding, well-being and independence. Relevant scores ranged from 3.71 to 4.76 . Peer relationship was the top ranked domain at the level of $\mathrm{M}=4.76$ and $\mathrm{SD}=1.27$. Physical ability was the lowest rank domain, that was classified as a perceived valid domain by the respondents, at the level of $\mathrm{M}=3.71$ and $\mathrm{SD}=1.56$. However, it was worth noting that its mean value was just slightly highly than 3.5. Two domains, i.e. physical appearance and family with mean value of 3.27 and 2.81 respectively, were classified as domains that would not be affected by adventure programs.
The mean value of self-esteem, which was supposed to be an example of general self as suggested by Hattie et al (1997), was 4.06 while compared with the mean value of general self at 3.93. The mean value of self-control, which was supposed to be an example of self-efficacy, was 4.06 while compared with the mean value of self-efficacy at 4.07. The mean value of satisfaction, which was supposed to be an example of well-being, was 4.66 while compared with the mean value of well-being at 4.29 .

There was a statistically moderate positive relationship between the domain of general self and its example (i.e. selfesteem) ( $r=0.53$, df $=339, \mathrm{p}<0.000)$. Campers with perceived improve in their general self tended to have perceived improve in their self-esteem and vice versa to a certain extent. Furthermore, there was a statistically moderate positive relationship between the domain of self-efficacy and its example (i.e. selfcontrol) $(\mathrm{r}=0.45, \mathrm{df}=334, \mathrm{p}<0.000)$. Campers with perceived improve in their self-efficacy tended to have perceived improve in their self-control and vice versa to a certain extent (see Table 7.) 
Table 7. Correlations between Eleven Domains of Self-concept and An example from Three Problematic Domains.

\begin{tabular}{|c|c|c|c|c|c|c|c|c|c|c|c|c|c|c|c|}
\hline & & $\begin{array}{l}\text { Physical } \\
\text { Ability }\end{array}$ & $\begin{array}{c}\text { Peer } \\
\text { Relatition- } \\
\text { ship }\end{array}$ & $\begin{array}{l}\text { General } \\
\text { Self }\end{array}$ & $\begin{array}{l}\text { Physical } \\
\text { Appear- } \\
\text { ance }\end{array}$ & $\begin{array}{c}\text { Self- } \\
\text { problem } \\
\text { Solving }\end{array}$ & $\begin{array}{c}\text { Confidenc } \\
\text { e }\end{array}$ & $\begin{array}{c}\text { Self- } \\
\text { efficacy }\end{array}$ & Family & $\begin{array}{c}\text { Self- } \\
\text { Under- } \\
\text { standing }\end{array}$ & $\begin{array}{c}\text { Well-bein } \\
\mathrm{g}\end{array}$ & $\begin{array}{l}\text { Independ- } \\
\text { ence }\end{array}$ & $\begin{array}{l}\text { Self- } \\
\text { esteem }\end{array}$ & $\begin{array}{l}\text { Self- } \\
\text { control }\end{array}$ & $\begin{array}{l}\text { Satisfact- } \\
\text { ion }\end{array}$ \\
\hline \multirow[t]{3}{*}{$\begin{array}{l}\text { Physical } \\
\text { Ability }\end{array}$} & $\begin{array}{l}\text { Pearson } \\
\text { Correlation }\end{array}$ & 1 & $.345(* *)$ & $.427(* *)$ & $.449(* *)$ & $.397(* *)$ & $.399(* *)$ & $.449(* *)$ & $.270(* *)$ & $.445(* *)$ & $.485(* *)$ & $.328(* *)$ & $.447(* *)$ & $.346(* *)$ & $.365(* *)$ \\
\hline & $\begin{array}{l}\text { Sig. } \\
\text { (2-tailed) }\end{array}$ & . & .000 & .000 & .000 & .000 & .000 & .000 & .000 & .000 & .000 & .000 & .000 & .000 & .000 \\
\hline & $\mathrm{N}$ & 339 & 338 & 339 & 338 & 335 & 338 & 334 & 335 & 339 & 339 & 339 & 339 & 339 & 339 \\
\hline \multirow{3}{*}{$\begin{array}{l}\text { Peer } \\
\text { Relationship }\end{array}$} & $\begin{array}{l}\text { Pearson } \\
\text { Correlation }\end{array}$ & $.345(* *)$ & 1 & $.420(* *)$ & $.289(* *)$ & $.488(* *)$ & $.490\left(^{* *}\right)$ & $.456(* *)$ & $.224(* *)$ & $.372(* *)$ & $.372(* *)$ & $.414(* *)$ & $.3311^{(* *)}$ & $.363(* *)$ & $.552(* *)$ \\
\hline & $\begin{array}{l}\text { Sig. } \\
\text { (2-tailed) }\end{array}$ & .000 & . & .000 & .000 & .000 & .000 & .000 & .000 & .000 & .000 & .000 & .000 & .000 & .000 \\
\hline & $\mathrm{N}$ & 338 & 338 & 338 & 337 & 334 & 337 & 333 & 334 & 338 & 338 & 338 & 338 & 338 & 338 \\
\hline \multirow[t]{3}{*}{ General Self } & $\begin{array}{l}\text { Pearson } \\
\text { Correlation }\end{array}$ & $\left..4277^{* *}\right)$ & $.420(* *)$ & 1 & $.728(* *)$ & $.498(* *)$ & $.488(* *)$ & $.452(* *)$ & $.376(* *)$ & $.456(* *)$ & $.378(* *)$ & $.437(* *)$ & $.529(* *)$ & $.532(* *)$ & $.395(* *)$ \\
\hline & $\begin{array}{l}\text { Sig. } \\
\text { (2-tailed) }\end{array}$ & .000 & .000 & & .000 & .000 & .000 & .000 & .000 & .000 & .000 & .000 & .000 & .000 & .000 \\
\hline & $\mathrm{N}$ & 339 & 338 & 339 & 338 & 335 & 338 & 334 & 335 & 339 & 339 & 339 & 339 & 339 & 339 \\
\hline \multirow[t]{2}{*}{$\begin{array}{l}\text { Physical } \\
\text { Appearance }\end{array}$} & $\begin{array}{l}\text { Pearson } \\
\text { Correlation }\end{array}$ & $.449(* *)$ & $.289(* *)$ & $.728(* *)$ & 1 & $.454(* *)$ & $.408\left(^{(* *)}\right.$ & $.413(* *)$ & $.480(* *)$ & $.381(* *)$ & $.368(* *)$ & $.399^{(* *)}$ & $.558(* *)$ & $\left..506{ }^{(* *}\right)$ & $.308(* *)$ \\
\hline & $\begin{array}{l}\text { Sig. } \\
\text { (2-tailed) }\end{array}$ & .000 & .000 & .000 & . & .000 & .000 & .000 & .000 & .000 & .000 & .000 & .000 & .000 & .000 \\
\hline \multirow{2}{*}{$\begin{array}{l}\text { Self-problem } \\
\text { Solving }\end{array}$} & $\begin{array}{l}\mathrm{N} \\
\text { Pearson }\end{array}$ & $\begin{array}{r}338 \\
.397(* *)\end{array}$ & $\begin{array}{r}337 \\
.488(* *)\end{array}$ & $\begin{array}{r}338 \\
.498(* *)\end{array}$ & $\begin{array}{r}338 \\
.454(* *)\end{array}$ & $\begin{array}{r}334 \\
1\end{array}$ & $\begin{array}{r}338 \\
.721(* *)\end{array}$ & $\begin{array}{r}333 \\
.590(* *)\end{array}$ & $\begin{array}{r}334 \\
.246^{(* * *)}\end{array}$ & $\begin{array}{r}338 \\
.375(* *)\end{array}$ & $\begin{array}{r}338 \\
.318(* *)\end{array}$ & $\begin{array}{r}338 \\
.362(* *)\end{array}$ & $\begin{array}{r}338 \\
477^{* * *}\end{array}$ & $\begin{array}{r}338 \\
412(* *)\end{array}$ & $\begin{array}{r}338 \\
.511(* *)\end{array}$ \\
\hline & $\begin{array}{l}\text { Correlation } \\
\text { Sig. }\end{array}$ & .000 & .000 & .000 & 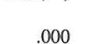 & 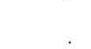 & & (6) & का & & otent & (6) & , & ont & , \\
\hline \multirow[t]{3}{*}{ Confidence } & $\begin{array}{l}\text { Pearson } \\
\text { Correlation }\end{array}$ & $.399(* *)$ & $.490(* *)$ & $.488(* *)$ & $.408(* *)$ & .721 (**) & 1 & $\begin{array}{r}5162 \\
.51 * *)\end{array}$ & .309(**) & $.513(* *)$ & $\begin{array}{r}330 \\
.459(* *)\end{array}$ & $.490(* *)$ & $\begin{array}{r}330 \\
.624(* *)\end{array}$ & $\begin{array}{r}.532(* *) \\
. * 25\end{array}$ & $.591(* *)$ \\
\hline & $\begin{array}{l}\text { Sig. } \\
\text { (2-tailed) }\end{array}$ & .000 & .000 & .000 & .000 & .000 & . & .000 & .000 & .000 & .000 & .000 & .000 & .000 & .000 \\
\hline & $\mathrm{N}$ & 338 & 337 & 338 & 338 & 334 & 338 & 333 & 334 & 338 & 338 & 338 & 338 & 338 & 338 \\
\hline \multirow[t]{3}{*}{ Self-efficacy } & $\begin{array}{l}\text { Pearson } \\
\text { Correlation }\end{array}$ & $.449(* *)$ & $.456\left({ }^{* *}\right)$ & $.452(* *)$ & $.413(* *)$ & $.590(* *)$ & $.516(* *)$ & 1 & $.322(* *)$ & $.435(* *)$ & $.429\left(^{* *}\right)$ & $.475(* *)$ & $.428\left(^{* *}\right)$ & $.452(* *)$ & $.482(* *)$ \\
\hline & $\begin{array}{l}\text { Sig. } \\
\text { (2-tailed) }\end{array}$ & .000 & .000 & .000 & .000 & .000 & .000 & & .000 & .000 & .000 & .000 & .000 & .000 & .000 \\
\hline & $\mathrm{N}$ & 334 & 333 & 334 & 333 & 332 & 333 & 334 & 331 & 334 & 334 & 334 & 334 & 334 & 334 \\
\hline \multirow[t]{3}{*}{ Family } & $\begin{array}{l}\text { Pearson } \\
\text { Correlation }\end{array}$ & $.270(* *)$ & $.224\left({ }^{* *}\right)$ & $.376(* *)$ & $.480(* *)$ & $.246(* *)$ & $.309(* *)$ & $.322(* *)$ & 1 & $.422(* *)$ & $.278(* *)$ & $.352(* *)$ & $.433(* *)$ & $.400(* *)$ & $.261(* *)$ \\
\hline & $\begin{array}{l}\text { Sig. } \\
\text { (2-tailed) }\end{array}$ & .000 & .000 & .000 & .000 & .000 & .000 & .000 & . & .000 & .000 & .000 & .000 & .000 & .000 \\
\hline & $\mathrm{N}$ & 335 & 334 & 335 & 334 & 332 & 334 & 331 & 335 & 335 & 335 & 335 & 335 & 335 & 335 \\
\hline \multirow[t]{3}{*}{$\begin{array}{l}\text { Self- } \\
\text { understanding }\end{array}$} & $\begin{array}{l}\text { Pearson } \\
\text { Correlation }\end{array}$ & $.445(* *)$ & $.372\left({ }^{* *}\right)$ & $.456\left({ }^{* *}\right)$ & $.381(* *)$ & $.375\left({ }^{* * *}\right)$ & $.513(* *)$ & $.435\left({ }^{* *}\right)$ & $.422(* *)$ & 1 & $.522\left({ }^{(* *)}\right.$ & $.498\left({ }^{* * *}\right)$ & $.592\left({ }^{(* *}\right)$ & $.559\left({ }^{(* *)}\right)$ & $.5311^{(* *)}$ \\
\hline & $\begin{array}{l}\text { Sig. } \\
\text { (2-tailed) }\end{array}$ & .000 & .000 & .000 & .000 & .000 & .000 & .000 & .000 & . & .000 & .000 & .000 & .000 & .000 \\
\hline & $\mathrm{N}$ & 339 & 338 & 339 & 338 & 335 & 338 & 334 & 335 & 339 & 339 & 339 & 339 & 339 & 339 \\
\hline \multirow[t]{3}{*}{ Well-being } & $\begin{array}{l}\text { Pearson } \\
\text { Correlation }\end{array}$ & $.485\left(^{\left({ }^{* * *}\right)}\right.$ & $.372(* *)$ & $.378\left({ }^{(* *}\right)$ & $.368\left({ }^{(* *)}\right)$ & $.318\left({ }^{(* *)}\right)$ & $.4599^{(* *)}$ & $.429\left({ }^{* * *}\right)$ & $.278(* *)$ & $.522(* *)$ & 1 & $.445(* *)$ & $.418(* *)$ & $.436\left({ }^{* *}\right)$ & $.462(* *)$ \\
\hline & $\begin{array}{l}\text { Sig. } \\
\text { (2-tailed) }\end{array}$ & .000 & .000 & .000 & .000 & .000 & .000 & .000 & .000 & .000 & & .000 & .000 & .000 & .000 \\
\hline & $\mathrm{N}$ & 339 & 338 & 339 & 338 & 335 & 338 & 334 & 335 & 339 & 339 & 339 & 339 & 339 & 339 \\
\hline \multirow[t]{3}{*}{ Independence } & $\begin{array}{l}\text { Pearson } \\
\text { Correlation }\end{array}$ & $.328\left({ }^{* *}\right)$ & $.414\left(^{* *}\right)$ & $.437\left(^{(* *)}\right.$ & $.3999^{(* *)}$ & $.362\left({ }^{* *}\right)$ & $.490(* *)$ & $.475(* *)$ & $.352(* *)$ & $.498(* *)$ & $.445\left(^{(* *)}\right.$ & 1 & $.596(* *)$ & $.557\left({ }^{* *}\right)$ & $\left..4822^{* *}\right)$ \\
\hline & $\begin{array}{l}\text { Sig. } \\
\text { (2-tailed) }\end{array}$ & .000 & .000 & .000 & .000 & .000 & .000 & .000 & .000 & .000 & .000 & . & .000 & .000 & .000 \\
\hline & $\mathrm{N}$ & 339 & 338 & 339 & 338 & 335 & 338 & 334 & 335 & 339 & 339 & 339 & 339 & 339 & 339 \\
\hline \multirow[t]{3}{*}{ Self-esteem } & $\begin{array}{l}\text { Pearson } \\
\text { Correlation }\end{array}$ & $.447(* *)$ & $.331\left({ }^{* *}\right)$ & $.529\left({ }^{* *}\right)$ & $.558(* *)$ & $.477(* *)$ & $.624(* *)$ & $.428(* *)$ & $.433(* *)$ & $.592(* *)$ & $.418\left({ }^{* *}\right)$ & $.596\left(^{(* *)}\right.$ & 1 & $.656\left({ }^{* * *}\right)$ & $.477(* *)$ \\
\hline & & .000 & .000 & .000 & .000 & .000 & .000 & .000 & .000 & .000 & .000 & .000 & . & .000 & .000 \\
\hline & $\mathrm{N}$ & 339 & 338 & 339 & 338 & 335 & 338 & 334 & 335 & 339 & 339 & 339 & 339 & 339 & 339 \\
\hline \multirow[t]{3}{*}{ Self-control } & $\begin{array}{l}\text { Pearson } \\
\text { Correlation }\end{array}$ & $.346\left(^{* * *}\right)$ & $.363(* *)$ & $.532\left({ }^{* *}\right)$ & $.506(* *)$ & $.412(* *)$ & $.532(* *)$ & $.452(* *)$ & $.400(* *)$ & $.559^{(* *)}$ & $.436(* *)$ & $.557\left({ }^{* *}\right)$ & $.656(* *)$ & 1 & $.504(* *)$ \\
\hline & $\begin{array}{l}\text { Sig. } \\
\text { (2-tailed) }\end{array}$ & .000 & .000 & .000 & .000 & .000 & .000 & .000 & .000 & .000 & .000 & .000 & .000 & . & .000 \\
\hline & $\mathrm{N}$ & 339 & 338 & 339 & 338 & 335 & 338 & 334 & 335 & 339 & 339 & 339 & 339 & 339 & 339 \\
\hline \multirow[t]{3}{*}{ Satisfaction } & $\begin{array}{l}\text { Pearson } \\
\text { Correlation }\end{array}$ & $.365\left({ }^{(* *}\right)$ & $.552(* *)$ & $.395\left({ }^{* *}\right)$ & $.308\left({ }^{* *}\right)$ & $.511\left({ }^{* *}\right)$ & $.591\left({ }^{(* *}\right)$ & $.482(* *)$ & $.261\left({ }^{(* *}\right)$ & $.5311^{(* *)}$ & $.462(* *)$ & $.482\left({ }^{* *}\right)$ & $.477(* *)$ & $.504(* *)$ & 1 \\
\hline & $\begin{array}{l}\text { Sig. } \\
\text { (2-tailed) }\end{array}$ & .000 & .000 & .000 & .000 & .000 & .000 & .000 & .000 & .000 & .000 & .000 & .000 & .000 & . \\
\hline & $\mathrm{N}$ & 339 & 338 & 339 & 338 & 335 & 338 & 334 & 335 & 339 & 339 & 339 & 339 & 339 & 339 \\
\hline
\end{tabular}

** Correlation is significant at the 0.05 level (2-tailed).

There was also a statistically moderate positive relationship between the domain of well-being and it's example (i.e. satisfaction) $(\mathrm{r}=0.46, \mathrm{df}=339, \mathrm{p}<0.01)$. Campers with perceived improve in their well-being tended to perceived improve in their satisfaction and vice versa to a certain extent. Such findings implied that the results of my study might really or unavoidably be affected by the use of language to some extent.
There were significant weak to moderate positive relationships ranging from $r=0.22$ to $r=0.72$ between eleven domains and one example for 3 different domains for testing validity. The lowest significant weak positive relationship was between family and peer relationship $(r=0.22, \mathrm{df}=$ $334, \mathrm{p}<0.01)$. The highest significant moderate positive relationship was between self-problem solving and confidence $(r=0.72, d f=334, p<0.01)$. For details, please refer to Table 7 above. 


\section{Factor Analysis for Domains of Self-concept}

A Factor analysis was used to identify the latent variables of self-concept's domains with perceived change (i.e. only nine domains of self-concept that had an average mean over 3.5). The nine domains (see Table 6) were physical ability, peer relationship, general self, self-problem solving, confidence, self-efficacy, self-understanding, well-being and independence. As the purpose of the analysis was to link variables together into factors, those domains must be related to one another (i.e. domains had correlation coefficient larger than about 0.3). In the present study, no additional domains had to be eliminated as correction coefficients among all said nine domains were over 0.3. For details, please refer to output "simplified correlation matrix" under Table 8.

The communalities, ranging from 0.44 to 0.64 , were the proportion of the variance of the test that had been accounted for by the factors extracted. The analysis in output "component matrix" suggested that only one component or factor could be extracted and the solution cannot be rotated. This meant that the present model was not able to replicate the original factors, thus mean differences of each items would then be utilized for further discussions.

Table 8. Simplified Correlation Matrix on Nine Domains with Perceived Change.

\begin{tabular}{|c|c|c|c|c|c|c|c|c|c|}
\hline & $\begin{array}{l}\text { Physica } \\
\text { Ability }\end{array}$ & $\begin{array}{c}\text { Peer } \\
\text { Relationship }\end{array}$ & $\begin{array}{c}\text { General } \\
\text { Self }\end{array}$ & $\begin{array}{l}\text { Self-problem } \\
\text { Solving }\end{array}$ & Confidence & $\begin{array}{l}\text { Self- } \\
\text { efficacy }\end{array}$ & $\begin{array}{c}\text { Self- } \\
\text { understanding }\end{array}$ & $\begin{array}{l}\text { Well- } \\
\text { being }\end{array}$ & Independence \\
\hline Physical Ability & 1.000 & .348 & .439 & .386 & .409 & .442 & .450 & .487 & .352 \\
\hline Peer Relationship & .348 & 1.000 & .408 & .483 & .484 & .457 & .359 & .364 & .426 \\
\hline General Self & .439 & .408 & 1.000 & .500 & .483 & .456 & .448 & .373 & .444 \\
\hline Self-problem Solving & .386 & .483 & .500 & 1.000 & .727 & .586 & .371 & .314 & .380 \\
\hline Confidence & .409 & .484 & .483 & .727 & 1.000 & .521 & .508 & .455 & .491 \\
\hline Self-efficacy & .442 & .457 & .456 & .586 & .521 & 1.000 & .436 & .430 & .485 \\
\hline Self-understanding & .450 & .359 & .448 & .371 & .508 & .436 & 1.000 & .515 & .517 \\
\hline Well-being & .487 & .364 & .373 & .314 & .455 & .430 & .515 & 1.000 & .462 \\
\hline Independence & .352 & .426 & .444 & .380 & .491 & .485 & .517 & .462 & 1.000 \\
\hline
\end{tabular}

\section{Difference in Eleven Domains of Self-concept by Gender}

The mean scores of ten out of eleven domains (except confidence) from male participants were not significantly different from female participants. In other words, the difference between the mean scores of most of the domains (except confidence) was not statistically significant at the two-tailed $5 \%$ level. The findings were listed as below:

(a) The mean physical ability score of male participants $(\mathrm{M}=3.76, \mathrm{SD}=1.54)$ was not significantly different $(\mathrm{t}=0.60$, df $=332$, two tailed $\mathrm{p}=0.547)$ from female participants $(\mathrm{M}=3.75, \mathrm{SD}=1.59)$.

(b) The mean peer relationship score of male participants $(\mathrm{M}=4.71, \mathrm{SD}=1.28)$ was not significantly different $(\mathrm{t}=-0.66$, df $=331$, two tailed $\mathrm{p}=0.509)$ from female participants $(M=4.80, S D=1.28)$.

(c) The mean general self score of male participants $(\mathrm{M}=4.05, \mathrm{SD}=1.49)$ was not significantly different $(\mathrm{t}=1.26$, $\mathrm{df}=332$, two tailed $\mathrm{p}=0.208)$ from female participants $(\mathrm{M}=3.8, \mathrm{SD}=1.61)$. (d) The mean physical appearance score of male participants $(\mathrm{M}=3.5, \mathrm{SD}=1.69)$ was not significantly different $(\mathrm{t}=2.20, \mathrm{df}=331$, two tailed $\mathrm{p}=0.029)$ from female participants $(\mathrm{M}=3.11, \mathrm{SD}=1.57)$.

(e) The mean self-problem solving score of male participants $(\mathrm{M}=4.29, \mathrm{SD}=1.60)$ was not significantly different $(\mathrm{t}=0.65$, df $=328$, two tailed $\mathrm{p}=0.520)$ from female participants $(\mathrm{M}=4.18, \mathrm{SD}=1.66)$.

(f) The mean confidence score of male participants $(\mathrm{M}=4.70, \mathrm{SD}=1.44)$ was significantly higher $(\mathrm{t}=2.31$, df $=331$, two tailed $\mathrm{p}=0.021)$ than female participants $(\mathrm{M}=4.32, \mathrm{SD}=1.50)$.

(g) The mean self-efficacy score of male participants $(\mathrm{M}=4.14, \mathrm{SD}=1.60)$ was not significantly different $(t=0.70, d f=327$, two tailed $p=0.485)$ from female participants $(\mathrm{M}=4.01, \mathrm{SD}=1.69)$.

(h) The mean family score of male participants ( $\mathrm{M}=$ $2.86, \mathrm{SD}=1.83)$ was not significantly different $(\mathrm{t}=$ $0.32, \mathrm{df}=328$, two tailed $\mathrm{p}=0.750$ ) from female participants $(\mathrm{M}=2.79, \mathrm{SD}=1.91)$. 
(i) The mean self-understanding score of male participants $(\mathrm{M}=4.27, \mathrm{SD}=1.54)$ was not significantly different $(\mathrm{t}=-0.48$, df $=332$, two tailed $\mathrm{p}=0.962)$ from female participants $(\mathrm{M}=4.28, \mathrm{SD}=1.53)$.

(j) The mean well-being score of male participants $(\mathrm{M}=4.45, \mathrm{SD}=1.39)$ was not significantly different $(\mathrm{t}=1.75$, df $=332$, two tailed $\mathrm{p}=0.081)$ from female participants $(\mathrm{M}=4.15, \mathrm{SD}=1.70)$. (k) The mean independent score of male participants $(\mathrm{M}=4.19, \mathrm{SD}=1.59)$ was not significantly different $(\mathrm{t}=-0.74$, df $=332$, two tailed $\mathrm{p}=0.460)$ from female participants $(\mathrm{M}=4.32, \mathrm{SD}=1.56)$.

On the whole, there should not be any overall significantly different between male and female participants in the mean scores of overall self-concept, except in the domain of confidence (see Table 9).

Table 9. Means of Standard Deviations of Eleven Domains of Gender.

\begin{tabular}{|c|c|c|c|c|}
\hline & Gender & $\mathbf{N}$ & Mean & Std. Deviation \\
\hline \multirow[t]{2}{*}{ Physical Ability } & Male & 144 & 3.76 & 1.53 \\
\hline & Female & 190 & 3.65 & 1.58 \\
\hline \multirow[t]{2}{*}{ Peer Relationship } & Male & 143 & 4.71 & 1.28 \\
\hline & Female & 190 & 4.80 & 1.27 \\
\hline \multirow[t]{2}{*}{ General Self } & Male & 144 & 4.05 & 1.48 \\
\hline & Female & 190 & 3.83 & 1.60 \\
\hline \multirow[t]{2}{*}{ Physical Appearance } & Male & 143 & 3.51 & 1.68 \\
\hline & Female & 190 & 3.11 & 1.65 \\
\hline \multirow[t]{2}{*}{ Self-problem Solving } & Male & 143 & 4.29 & 1.60 \\
\hline & Female & 187 & 4.18 & 1.66 \\
\hline \multirow[t]{2}{*}{ Confidence } & Male & 143 & 4.70 & 1.44 \\
\hline & Female & 190 & 4.32 & 1.50 \\
\hline \multirow[t]{2}{*}{ Self-efficacy } & Male & 144 & 4.14 & 1.60 \\
\hline & Female & 185 & 4.01 & 1.68 \\
\hline \multirow[t]{2}{*}{ Family } & Male & 142 & 2.86 & 1.83 \\
\hline & Female & 188 & 2.79 & 1.91 \\
\hline \multirow[t]{2}{*}{ Self-understanding } & Male & 144 & 4.27 & 1.54 \\
\hline & Female & 190 & 4.28 & 1.53 \\
\hline \multirow[t]{2}{*}{ Well-being } & Male & 144 & 4.45 & 1.38 \\
\hline & Female & 190 & 4.15 & 1.69 \\
\hline \multirow[t]{2}{*}{ Independence } & Male & 144 & 4.19 & 1.58 \\
\hline & Female & 190 & 4.32 & 1.55 \\
\hline
\end{tabular}

\section{Difference in Eleven Domains of Self-concept by Age}

Once the youth reached age of 18 , they were being treated and classified as an adult. Besides, most of them should have completed secondary education. As such, I cut the samples into two groups, one was age under 18 whereas another was age of 18 or above to see whether there were any difference in their perceived changes in various domains of self-concept. The results were contradictory in different domains and listed below:

(a) The mean physical ability score of participants aged 18 and above $(\mathrm{M}=3.82, \mathrm{SD}=1.53)$ was not significantly different $(\mathrm{t}=0.81$, df $=330$, two-tailed $\mathrm{p}=0.417)$ from participants aged below $18(\mathrm{M}=3.66, \mathrm{SD}=$ $1.59)$. (b) The mean peer relationship score of participant aged 18 and above $(M=4.97, S D=0.93)$ was significantly higher $(\mathrm{t}=2.29$, $\mathrm{df}=244$, two-tailed $\mathrm{p}=0.023)$ than participants aged below $18(\mathrm{M}=4.67, \mathrm{SD}=1.38)$.

(c) The mean general self score of participant aged 18 and above $(\mathrm{M}=4.28, \mathrm{SD}=1.28)$ was significantly higher $(\mathrm{t}=2.99, \mathrm{df}=209$, two-tailed $\mathrm{p}=0.003)$ than participants aged below $18(\mathrm{M}=3.78, \mathrm{SD}=1.63)$.

(d) The mean physical appearance score of participant aged 18 and above $(\mathrm{M}=3.60, \mathrm{SD}=1.45)$ was significantly higher $(\mathrm{t}=2.45$, $\mathrm{df}=198$, two-tailed $\mathrm{p}=0.015)$ than participants aged below $18(\mathrm{M}=3.13, \mathrm{SD}=1.75)$. 
(e) The mean self-problem solving score of participant aged 18 and above $(\mathrm{M}=4.57, \mathrm{SD}=1.22)$ was significantly higher $(t=2.80$, df $=229$, two-tailed $p=0.006)$ than participants aged below $18(\mathrm{M}=4.09, \mathrm{SD}=1.75)$.

(f) The mean confidence score of participants aged 18 and above $(\mathrm{M}=4.75, \mathrm{SD}=1.32)$ was not significantly different $(\mathrm{t}=2.20, \mathrm{df}=191$, two-tailed $\mathrm{p}=0.029)$ from participants aged below $18(\mathrm{M}=4.38, \mathrm{SD}=1.54)$.

(g) The mean self-efficacy score of participant aged 18 and above $(\mathrm{M}=4.58, \mathrm{SD}=1.22)$ was significantly higher $(\mathrm{t}=4.14, \mathrm{df}=233$, two-tailed $\mathrm{p}=0.000)$ than participants aged below $18(\mathrm{M}=3.87, \mathrm{SD}=1.75)$.

(h) The mean family score of participants aged 18 and above $(\mathrm{M}=2.69, \mathrm{SD}=1.89)$ was not significantly different $(\mathrm{t}=-0.67, \mathrm{df}=326$, two-tailed $\mathrm{p}=0.504)$ from participants aged below $18(\mathrm{M}=2.84, \mathrm{SD}=1.88)$.

(i) The mean self-understanding score of participants aged 18 and above $(M=4.49, S D=1.36)$ was not significantly different $(t=1.53$, df $=330$, two-tailed $p=0.126)$ from participants aged below $18(\mathrm{M}=4.20, \mathrm{SD}=$ $1.60)$.

(j) The mean well-being score of participant aged 18 and above $(\mathrm{M}=4.65, \mathrm{SD}=1.22)$ was significantly higher $(\mathrm{t}=3.03, \mathrm{df}=227$, two-tailed $\mathrm{p}=0.003)$ than participants aged below $18(\mathrm{M}=4.15, \mathrm{SD}=1.68)$.

(k) The mean independence score of participant aged 18 and above $(M=4.64, S D=1.14)$ was significantly higher $(\mathrm{t}=3.41, \mathrm{df}=240$, two-tailed $\mathrm{p}=0.001)$ than participants aged below $18(\mathrm{M}=4.09, \mathrm{SD}=1.68)$.

The mean scores of physical ability, confidence, family and self-understanding of participants aged 18 and above were not significantly different from participants aged below 18 . On the other hand, the mean scores of peer relationship, general self, physical appearance, self-problem solving, self-efficacy, well being and independence of participant aged 18 and above were significantly higher than participants aged below 18 Further studies may be required to explore the causes of difference (see Table 10).

Table 10. Means and Standard Deviations of Eleven Domains by Age.

\begin{tabular}{|c|c|c|c|c|}
\hline & Age & $\mathbf{N}$ & Mean & Std. Deviation \\
\hline \multirow[t]{2}{*}{ Physical Ability } & $>=18$ & 92 & 3.82 & 1.53 \\
\hline & $<18$ & 240 & 3.66 & 1.59 \\
\hline \multirow[t]{2}{*}{ Peer Relationship } & $>=18$ & 92 & 4.97 & 0.93 \\
\hline & $<18$ & 239 & 4.67 & 1.38 \\
\hline \multirow[t]{2}{*}{ General Self } & $>=18$ & 92 & 4.28 & 1.27 \\
\hline & $<18$ & 240 & 3.78 & 1.63 \\
\hline \multirow[t]{2}{*}{ Physical Appearance } & $>=18$ & 92 & 3.60 & 1.45 \\
\hline & $<18$ & 239 & 3.13 & 1.75 \\
\hline \multirow[t]{2}{*}{ Self-problem Solving } & $>=18$ & 90 & 4.57 & 1.21 \\
\hline & $<18$ & 239 & 4.09 & 1.74 \\
\hline \multirow[t]{2}{*}{ Confidence } & $>=18$ & 92 & 4.75 & 1.32 \\
\hline & $<18$ & 239 & 4.38 & 1.54 \\
\hline \multirow[t]{2}{*}{ Self-efficacy } & $>=18$ & 91 & 4.58 & 1.22 \\
\hline & $<18$ & 238 & 3.87 & 1.75 \\
\hline \multirow[t]{2}{*}{ Family } & $>=18$ & 90 & 2.69 & 1.88 \\
\hline & $<18$ & 238 & 2.84 & 1.88 \\
\hline \multirow[t]{2}{*}{ Self-understanding } & $>=18$ & 92 & 4.49 & 1.35 \\
\hline & $<18$ & 240 & 4.20 & 1.60 \\
\hline \multirow[t]{2}{*}{ Well-being } & $>=18$ & 92 & 4.65 & 1.21 \\
\hline & $<18$ & 240 & 4.15 & 1.68 \\
\hline \multirow[t]{2}{*}{ Independence } & $>=18$ & 92 & 4.64 & 1.14 \\
\hline & $<18$ & 240 & 4.09 & 1.67 \\
\hline
\end{tabular}




\section{Difference in Eleven Domains of Self concept by Length of Adventure Program}

The mean scores of ten out of eleven domains (except independence) of participants attended residential camps with 3 or more sessions of adventure activities was not significantly different from day camps with less than 3 sessions of adventure activities. Perhaps not staying overnight at home already provided the perception of independence to youth participants of camp adventure programs. The detailed figures were listed in Table 13 and Table 14.

(a) The mean physical ability score of attending residential camps $(\mathrm{M}=3.71, \mathrm{SD}=1.52)$ was not significantly different $(\mathrm{t}=0.18, \mathrm{df}=337$, two-tailed $\mathrm{p}=0.861)$ from attending day camps $(\mathrm{M}=3.68, \mathrm{SD}=1.66)$.

(b) The mean peer relationship score of residential camps $(\mathrm{M}=4.85, \mathrm{SD}=1.20)$ was not significantly different $(\mathrm{t}=1.88, \mathrm{df}=173$, two-tailed $\mathrm{p}=0.62)$ from attending day camps $(\mathrm{M}=4.56, \mathrm{SD}=1.40)$.

(c) The general self mean score of residential camps $(M=4.00, S D=1.58)$ was not significantly different $(\mathrm{t}=1.14, \mathrm{df}=337$, two-tailed $\mathrm{p}=0.257)$ from attending day camps $(\mathrm{M}=3.79, \mathrm{SD}=1.48)$.

(d) The mean physical appearance score of residential camps $(\mathrm{M}=3.27, \mathrm{SD}=1.68)$ was not significantly different $(\mathrm{t}=0.02, \mathrm{df}=336$, two-tailed $\mathrm{p}=0.983)$ from attending day camps $(\mathrm{M}=3.27, \mathrm{SD}=1.67)$. (e) The mean self-problem solving score of residential camps $(\mathrm{M}=4.25, \mathrm{SD}=1.62)$ was not significantly different $(\mathrm{t}=0.27, \mathrm{df}=333$, two-tailed $\mathrm{p}=0.785)$ from attending day camps $(\mathrm{M}=4.20, \mathrm{SD}=1.64)$.

(f) The mean confidence score of residential camps $(\mathrm{M}=4.52, \mathrm{SD}=1.44)$ was not significantly different $(\mathrm{t}=0.56, \mathrm{df}=336$, two-tailed $\mathrm{p}=0.574)$ from attending day camps $(\mathrm{M}=4.42, \mathrm{SD}=1.58)$.

(g) The mean self-efficacy score of residential camps $(\mathrm{M}=4.18, \mathrm{SD}=1.56)$ was not significantly different $(\mathrm{t}=1.72, \mathrm{df}=332$, two-tailed $\mathrm{p}=0.087)$ from attending day camps $(\mathrm{M}=3.84, \mathrm{SD}=1.80)$.

(h) The mean family score of residential camps $(\mathrm{M}=2.89, \mathrm{SD}=1.85)$ was not significantly different $(\mathrm{t}=1.22, \mathrm{df}=333$, two-tailed $\mathrm{p}=0.223)$ from attending day camps $(\mathrm{M}=2.62, \mathrm{SD}=1.93)$.

(i) The mean self-understanding score of residential camps $(\mathrm{M}=4.40, \mathrm{SD}=1.41)$ was not significantly different $(\mathrm{t}=1.87, \mathrm{df}=164$, two-tailed $\mathrm{p}=0.063)$ from attending day camps $(\mathrm{M}=4.04, \mathrm{SD}=1.78)$.

(j) The mean well-being score of residential camps $(\mathrm{M}=4.24, \mathrm{SD}=1.55)$ was not significantly different $(\mathrm{t}=-0.90, \mathrm{df}=337$, two-tailed $\mathrm{p}=0.371)$ from attending day camps $(\mathrm{M}=4.40, \mathrm{SD}=1.61)$.

(k) The mean independence score of residential camps $(\mathrm{M}=4.42, \mathrm{SD}=1.45)$ was significantly higher $(\mathrm{t}=2.83, \mathrm{df}=337$, two-tailed $\mathrm{p}=0.005)$ than attending day camps $(\mathrm{M}=3.90, \mathrm{SD}=1.73)$ 
Table 11. Mean and Standard Deviations of Eleven Domains by Length of Adventure Programs

\begin{tabular}{|c|c|c|c|c|}
\hline & $\begin{array}{l}\text { Activity } \\
\text { Session }\end{array}$ & $\mathbf{N}$ & Mean & Std. Deviation \\
\hline \multirow[t]{2}{*}{ Physical Ability } & $>=3$ & 235 & 3.71 & 1.51 \\
\hline & $<3$ & 104 & 3.68 & 1.66 \\
\hline \multirow[t]{2}{*}{ Peer Relationship } & $>=3$ & 234 & 4.85 & 1.20 \\
\hline & $<3$ & 104 & 4.56 & 1.39 \\
\hline \multirow[t]{2}{*}{ General Self } & $>=3$ & 235 & 4.00 & 1.58 \\
\hline & $<3$ & 104 & 3.79 & 1.47 \\
\hline \multirow[t]{2}{*}{ Physical Appearance } & $>=3$ & 234 & 3.27 & 1.68 \\
\hline & $<3$ & 104 & 3.27 & 1.66 \\
\hline \multirow[t]{2}{*}{ Self-problem Solving } & $>=3$ & 233 & 4.25 & 1.62 \\
\hline & $<3$ & 102 & 4.20 & 1.63 \\
\hline \multirow[t]{2}{*}{ Confidence } & $>=3$ & 234 & 4.52 & 1.43 \\
\hline & $<3$ & 104 & 4.42 & 1.57 \\
\hline \multirow[t]{2}{*}{ Self-efficacy } & $>=3$ & 233 & 4.18 & 1.55 \\
\hline & $<3$ & 101 & 3.84 & 1.80 \\
\hline \multirow[t]{2}{*}{ Family } & $>=3$ & 232 & 2.89 & 1.85 \\
\hline & $<3$ & 103 & 2.62 & 1.93 \\
\hline \multirow[t]{2}{*}{ Self-understanding } & $>=3$ & 235 & 4.40 & 1.40 \\
\hline & $<3$ & 104 & 4.04 & 1.75 \\
\hline \multirow[t]{2}{*}{ Well-being } & $>=3$ & 235 & 4.24 & 1.55 \\
\hline & $<3$ & 104 & 4.40 & 1.61 \\
\hline \multirow[t]{2}{*}{ Independence } & $>=3$ & 235 & 4.42 & 1.45 \\
\hline & $<3$ & 104 & 3.90 & 1.72 \\
\hline
\end{tabular}

\section{Program Components and Factors}

Seven questions were asked to obtain opinions from respondents on the Walsh and Golin's (1976) Outward Bound components/factors contributed to the change. The range of the answers were also 1 to 6 , which represented from ìstrongly disagreeî to ìstrongly agreeî respectively. A mean value of
3.5 would be the middle point of the range and any score higher than this point represented tendency towards the ìmore agreeableî and could be identified as a potential components/ factor contributed to the change. Table 12 showed the corresponding values of mean and standard deviation of different factors/components.

Table 12. Means and Standard Deviations of Program Factors and Components.

\begin{tabular}{lllll}
\hline & Count & Valid N & Mean & Standard Deviation \\
\hline Participant's Characteristics & 339 & $\mathrm{~N}=339$ & 3.81 & 1.55 \\
Physical Environment & 339 & $\mathrm{~N}=339$ & 4.20 & 1.42 \\
Social Environment & 339 & $\mathrm{~N}=337$ & 4.56 & 1.45 \\
Program Activities & 339 & $\mathrm{~N}=339$ & 4.29 & 1.57 \\
Instructors & 339 & $\mathrm{~N}=339$ & 4.43 & 1.56 \\
Mastery & 339 & $\mathrm{~N}=339$ & 4.65 & 1.42 \\
Reflection & 339 & $\mathrm{~N}=338$ & 4.52 & 1.57 \\
\hline
\end{tabular}

All factors/components scored with mean higher than 3.5 and were classified as perceived factors/components contributed to the change. The means ranged from 3.81 to 4.65 . Mastery was the top ranked factor/component at the level of $\mathrm{M}=$ 4.65 and $\mathrm{SD}=1.42$. Participant's characteristics was the lowest rank factor, that was classified as a valid factor, at the level of $\mathrm{M}=3.81$ and $\mathrm{SD}=1.56$. Other factors or components were with means over 4.0. Reflection was the factor with the second highest mean at 4.52. The means of other factors or components were in the descending order of social environment (4.56), instructors (4.43), program activities (4.29) and physical environment (4.20). 
There were significant weak to moderate positive relationships (ranging from $r=0.35$ to $r=0.56$ ) between seven components and factors in revised Golin's and Walsh Outward Bound Model. The lowest significant weak positive relationship was between participant's characteristics and reflection $(\mathrm{r}=0.35 \mathrm{df}=338$, $p<0.000$ ). The highest significant moderate positive relationship was between program activities and social environment $(r=$ 0.60 , df $=337, p<0.000)$. For details, see Table 13 .

Table 13. Correlations between Adventure Components/Factors.

\begin{tabular}{|c|c|c|c|c|c|c|c|c|}
\hline & & $\begin{array}{c}\text { Participant's } \\
\text { Characteristi } \\
\text { cs }\end{array}$ & $\begin{array}{c}\text { Physical } \\
\text { Environment }\end{array}$ & $\begin{array}{c}\text { Social } \\
\text { Environment }\end{array}$ & $\begin{array}{l}\text { Program } \\
\text { Activities }\end{array}$ & Instructors & Mastery & Reflection \\
\hline \multirow[t]{3}{*}{$\begin{array}{l}\text { Participant's } \\
\text { Characteristics }\end{array}$} & $\begin{array}{l}\text { Pearson } \\
\text { Correlation }\end{array}$ & 1 & $.433(* *)$ & $.545(* *)$ & $.423(* *)$ & $.376(* *)$ & $.433(* *)$ & $.349(* *)$ \\
\hline & $\begin{array}{l}\text { Sig. } \\
\text { (2-tailed) }\end{array}$ & . & .000 & .000 & .000 & .000 & .000 & .000 \\
\hline & $\mathbf{N}$ & 339 & 339 & 337 & 339 & 339 & 339 & 338 \\
\hline \multirow[t]{3}{*}{$\begin{array}{l}\text { Physical } \\
\text { Environment }\end{array}$} & $\begin{array}{l}\text { Pearson } \\
\text { Correlation }\end{array}$ & $.433(* *)$ & 1 & $.550(* *)$ & $.534(* *)$ & $.410(* *)$ & $.468(* *)$ & $.413(* *)$ \\
\hline & $\begin{array}{l}\text { Sig. } \\
\text { (2-tailed) }\end{array}$ & .000 & . & .000 & .000 & .000 & .000 & .000 \\
\hline & $\mathrm{N}$ & 339 & 339 & 337 & 339 & 339 & 339 & 338 \\
\hline \multirow[t]{3}{*}{$\begin{array}{l}\text { Social } \\
\text { Environment }\end{array}$} & $\begin{array}{l}\text { Pearson } \\
\text { Correlation }\end{array}$ & $.545(* *)$ & $.550(* *)$ & 1 & $.597(* *)$ & $.537(* *)$ & $.556(* *)$ & $.482(* *)$ \\
\hline & $\begin{array}{l}\text { Sig. } \\
\text { (2-tailed) }\end{array}$ & .000 & .000 & . & .000 & .000 & .000 & .000 \\
\hline & $\mathrm{N}$ & 337 & 337 & 337 & 337 & 337 & 337 & 336 \\
\hline \multirow[t]{3}{*}{$\begin{array}{l}\text { Program } \\
\text { Activities }\end{array}$} & $\begin{array}{l}\text { Pearson } \\
\text { Correlation }\end{array}$ & $.423(* *)$ & $.534(* *)$ & $.597(* *)$ & 1 & $.532(* *)$ & $.525(* *)$ & $.449(* *)$ \\
\hline & $\begin{array}{l}\text { Sig. } \\
\text { (2-tailed) }\end{array}$ & .000 & .000 & .000 & . & .000 & .000 & .000 \\
\hline & $\mathrm{N}$ & 339 & 339 & 337 & 339 & 339 & 339 & 338 \\
\hline \multirow[t]{3}{*}{ Instructors } & $\begin{array}{l}\text { Pearson } \\
\text { Correlation }\end{array}$ & $.376(* *)$ & $.410(* *)$ & $.537(* *)$ & $.532(* *)$ & 1 & $.563(* *)$ & $.528(* *)$ \\
\hline & $\begin{array}{l}\text { Sig. } \\
\text { (2-tailed) }\end{array}$ & .000 & .000 & .000 & .000 & · & .000 & .000 \\
\hline & $\mathrm{N}$ & 339 & 339 & 337 & 339 & 339 & 339 & 338 \\
\hline \multirow[t]{3}{*}{ Mastery } & $\begin{array}{l}\text { Pearson } \\
\text { Correlation }\end{array}$ & $.433(* *)$ & $.468(* *)$ & $.556(* *)$ & $.525(* *)$ & $.563(* *)$ & 1 & $.582(* *)$ \\
\hline & $\begin{array}{l}\text { Sig. } \\
\text { (2-tailed) }\end{array}$ & .000 & .000 & .000 & .000 & .000 & . & .000 \\
\hline & $\mathrm{N}$ & 339 & 339 & 337 & 339 & 339 & 339 & 338 \\
\hline \multirow[t]{3}{*}{ Reflection } & $\begin{array}{l}\text { Pearson } \\
\text { Correlation }\end{array}$ & $.349(* *)$ & $.413(* *)$ & $.482(* *)$ & $.449(* *)$ & $.528(* *)$ & $.582(* *)$ & 1 \\
\hline & $\begin{array}{l}\text { Sig. } \\
(2 \text {-tailed) }\end{array}$ & .000 & .000 & .000 & .000 & .000 & .000 & . \\
\hline & $\mathrm{N}$ & 338 & 338 & 336 & 338 & 338 & 338 & 338 \\
\hline
\end{tabular}

** Correlation is significant at the 0.05 level (2-tailed).

\section{Difference in Seven Adventure Components/Factors by Gender}

The mean scores of all components and factors of perceived change of male participants were not significantly different from female participants. Details of the findings, which were listed in Table 14 and Table 15, were as follows:

(a) The mean participant's characteristics score of male participants $(\mathrm{M}=3.92, \mathrm{SD}=1.54$ ) was not significantly different $(t=1.14$, $d f=332$, two-tailed $p=0.25)$ from female participants $(\mathrm{M}=3.73, \mathrm{SD}=1.59)$. (b) The mean physical environment score of male participants $(\mathrm{M}=4.37, \mathrm{SD}=1.23)$ was not significantly different $(\mathrm{t}=1.91, \mathrm{df}=332$, two-tailed $\mathrm{p}=0.057)$ from female participants $(\mathrm{M}=4.07, \mathrm{SD}=1.55)$.

(c) The mean social environment score of male participants $(\mathrm{M}=4.41, \mathrm{SD}=1.48)$ was not significantly different $(\mathrm{t}=-1.55, \mathrm{df}=330$, two-tailed $\mathrm{p}=0.121)$ from female participants $(\mathrm{M}=4.66, \mathrm{SD}=1.43)$. 
(d) The mean program activities score of male participants $(\mathrm{M}=4.35, \mathrm{SD}=1.51)$ was not significantly different $(\mathrm{t}=0.54, \mathrm{df}=332$, two-tailed $\mathrm{p}=0.590)$ from female participants $(M=4.25, \mathrm{SD}=1.64)$.

(e) The mean instructors score of male participants $(\mathrm{M}=$ $4.28, \mathrm{SD}=1.68)$ was not significantly different $(\mathrm{t}=$ -1.43, df $=332$, two-tailed $\mathrm{p}=0.153$ ) from female participants $(\mathrm{M}=4.53, \mathrm{SD}=1.48)$. (f) The mean mastery score of male participants $(\mathrm{M}=$ $4.58, \mathrm{SD}=1.51)$ was not significantly different $(\mathrm{t}=$ -0.71 , df $=332$, two-tailed $p=0.479$ ) from female participants $(\mathrm{M}=4.69, \mathrm{SD}=1.35)$.

(g) The mean reflection score of male participants ( $\mathrm{M}=$ $4.58, \mathrm{SD}=1.44)$ was not significantly different $(\mathrm{t}=$ $0.67, \mathrm{df}=331$, two-tailed $\mathrm{p}=0.505$ ) from female participants $(\mathrm{M}=4.46, \mathrm{SD}=1.67)$.

Table 14. Means and Standard Deviations of Seven Adventure Components/Factors by Gender.

\begin{tabular}{lllll}
\hline & Gender & N & Mean & Std. Deviation \\
\hline Participant's Characteristics & Male & 144 & 3.92 & 1.53 \\
& Female & 190 & 3.73 & 1.58 \\
Physical Environment & Male & 144 & 4.37 & 1.23 \\
& Female & 190 & 4.07 & 1.55 \\
Social Environment & Male & 143 & 4.41 & 1.48 \\
& Female & 189 & 4.66 & 1.43 \\
Program Activities & Male & 144 & 4.35 & 1.51 \\
\multirow{3}{*}{ Instructors } & Female & 190 & 4.25 & 1.63 \\
\multirow{3}{*}{ Mastery } & Male & 144 & 4.28 & 1.67 \\
\multirow{2}{*}{ Reflection } & Female & 190 & 4.53 & 1.48 \\
& Male & 144 & 4.58 & 1.51 \\
& Female & 190 & 4.69 & 1.35 \\
& Male & 144 & 4.58 & 1.43 \\
\hline
\end{tabular}

Table 15. Unrelated t-test Output between Gender and Seven Adventure Components/Factors.

\begin{tabular}{|c|c|c|c|c|c|c|}
\hline & \multicolumn{3}{|c|}{$\begin{array}{l}\text { Levene's Test for } \\
\text { Equality of Variances }\end{array}$} & \multicolumn{3}{|c|}{ t-test for Equality of Means } \\
\hline & & $\mathrm{F}$ & $\mathrm{P}$ & $\mathrm{t}$ & df & $\mathrm{p}$ \\
\hline \multirow[t]{2}{*}{ Participant's Characteristics } & Equal variances assumed & .022 & .883 & 1.142 & 332 & .254 \\
\hline & Equal variances not assumed & & & 1.146 & 312.47 & .252 \\
\hline \multirow[t]{2}{*}{ Physical Environment } & Equal variances assumed & 1.230 & .268 & 1.907 & 332 & .057 \\
\hline & Equal variances not assumed & & & 1.967 & 331.19 & .050 \\
\hline \multirow[t]{2}{*}{ Social Environment } & Equal variances assumed & .369 & .544 & -1.553 & 330 & .121 \\
\hline & Equal variances not assumed & & & -1.545 & 300.38 & .123 \\
\hline \multirow[t]{2}{*}{ Program Activities } & Equal variances assumed & .223 & .637 & .540 & 332 & .590 \\
\hline & Equal variances not assumed & & & .546 & 319.50 & .585 \\
\hline \multirow[t]{2}{*}{ Instructors } & Equal variances assumed & 2.255 & .134 & -1.433 & 332 & .153 \\
\hline & Equal variances not assumed & & & -1.409 & 286.34 & .160 \\
\hline \multirow[t]{2}{*}{ Mastery } & Equal variances assumed & 1.299 & .255 & -.708 & 332 & .479 \\
\hline & Equal variances not assumed & & & -.697 & 288.82 & .486 \\
\hline \multirow[t]{2}{*}{ Reflection } & Equal variances assumed & 1.452 & .229 & .667 & 331 & .505 \\
\hline & Equal variances not assumed & & & .680 & 326.14 & .497 \\
\hline
\end{tabular}




\section{Difference in Seven Adventure Components /Factors by Age}

The mean scores of all components and factors of perceived changes of participants aged 18 and over were significantly higher than participants aged below 18. Details of findings, which were listed in Table 16 and Table 17, were as below.

(a) The mean participant's characteristics score of participants aged 18 and over $(M=4.12, S D=1.18)$ was significantly higher $(t=2.72$, $d f=234$, two-tailed $\mathrm{p}=0.007)$ than participants aged below $18(\mathrm{M}=3.68, \mathrm{SD}=1.68)$.

(b) The mean physical environment score of participants aged 18 and over $(\mathrm{M}=4.47, \mathrm{SD}=1.03)$ was significantly higher $(\mathrm{t}=2.56$, $\mathrm{df}=245$, two-tailed $\mathrm{p}=0.011)$ than participants aged below $18(\mathrm{M}=4.09, \mathrm{SD}=1.54)$.

(c) The mean social environment score of participants aged 18 and over $(\mathrm{M}=4.88, \mathrm{SD}=0.97)$ was significantly higher $(t=3.28$, df $=267$, two-tailed $\mathrm{p}=0.001)$ than participants aged below $18(\mathrm{M}=4.41, \mathrm{SD}=1.59)$. (d) The mean program activities score of participants aged 18 and over $(M=4.61, S D=1.195)$ was significantly higher $(\mathrm{t}=2.74$, df $=232$, two-tailed $\mathrm{p}=0.007$ ) than participants aged below $18(\mathrm{M}=4.15, \mathrm{SD}=1.69)$.

(e) The mean instructors score of participants aged 18 and over $(M=4.80, S D=1.22)$ was significantly higher $(\mathrm{t}=3.10, \mathrm{df}=222$, two-tailed $\mathrm{p}=0.002)$ than participants aged below $18(\mathrm{M}=4.29, \mathrm{SD}=1.64)$.

(f) The mean mastery score of participants aged 18 and over $(\mathrm{M}=4.95, \mathrm{SD}=1.01)$ was significantly higher $(\mathrm{t}=2.87, \mathrm{df}=251$, two-tailed $\mathrm{p}=0.004)$ than participants aged below $18(\mathrm{M}=4.53, \mathrm{SD}=1.54)$.

(g) The mean reflection score of participants aged 18 and over $(M=4.81, S D=1.26)$ was significantly higher $(\mathrm{t}=2.50, \mathrm{df}=215$, two-tailed $\mathrm{p}=0.013)$ than participants aged below $18(\mathrm{M}=4.39, \mathrm{SD}=1.67)$.

Table 16. Means and Standard Deviations of Seven Adventure Components/Factors by Age.

\begin{tabular}{lllll}
\hline & Age & N & Mean & Std. Deviation \\
\hline Participant's Characteristics & $>=18$ & 92 & 4.12 & 1.17 \\
Physical Environment & $<18$ & 240 & 3.68 & 1.67 \\
Social Environment & $>=18$ & 92 & 4.47 & 1.03 \\
& $<18$ & 240 & 4.09 & 1.54 \\
Program Activities & $>=18$ & 92 & 4.88 & .97 \\
& $<18$ & 238 & 4.41 & 1.58 \\
Instructors & $>=18$ & 92 & 4.61 & 1.19 \\
Mastery & $<18$ & 240 & 4.15 & 1.69 \\
Reflection & $>=18$ & 92 & 4.80 & 1.21 \\
& $>18$ & 240 & 4.29 & 1.64 \\
& $>=18$ & 92 & 4.95 & 1.00 \\
& $>18$ & 240 & 4.53 & 1.54 \\
& $>=18$ & 91 & 4.81 & 1.25 \\
\hline
\end{tabular}


Table 17. Unrelated t-test Output between Age and Seven Adventure Components/Factors.

\begin{tabular}{|c|c|c|c|c|c|c|}
\hline & & \multicolumn{2}{|c|}{$\begin{array}{l}\text { Levene's Test for } \\
\text { Equality of Variances }\end{array}$} & t-test for & \multicolumn{2}{|c|}{ Equality of Means } \\
\hline & & F & Sig. & $\mathrm{t}$ & $\mathrm{df}$ & $\mathrm{p}$ \\
\hline \multirow{2}{*}{ Participant's Characteristics } & Equal variances assumed & 14.119 & .000 & 2.334 & 330 & .020 \\
\hline & Equal variances not assumed & & & 2.720 & 233.918 & .007 \\
\hline \multirow[t]{2}{*}{ Physical Environment } & Equal variances assumed & 3.977 & .047 & 2.159 & 330 & .032 \\
\hline & Equal variances not assumed & & & 2.564 & 245.023 & .011 \\
\hline \multirow[t]{2}{*}{ Social Environment } & Equal variances assumed & 14.471 & .000 & 2.669 & 328 & .008 \\
\hline & Equal variances not assumed & & & 3.277 & 267.015 & .001 \\
\hline \multirow[t]{2}{*}{ Program Activities } & Equal variances assumed & 5.523 & .019 & 2.361 & 330 & .019 \\
\hline & Equal variances not assumed & & & 2.744 & 232.235 & .007 \\
\hline \multirow[t]{2}{*}{ Instructors } & Equal variances assumed & 7.639 & .006 & 2.719 & 330 & .007 \\
\hline & Equal variances not assumed & & & 3.102 & 221.749 & .002 \\
\hline \multirow[t]{2}{*}{ Mastery } & Equal variances assumed & 14.279 & .000 & 2.397 & 330 & .017 \\
\hline & Equal variances not assumed & & & 2.873 & 250.659 & .004 \\
\hline \multirow[t]{2}{*}{ Reflection } & Equal variances assumed & 7.996 & .005 & 2.208 & 329 & .028 \\
\hline & Equal variances not assumed & & & 2.504 & 214.617 & .013 \\
\hline
\end{tabular}

\section{Difference in Seven Adventure Components/Factors by Length of Adventure Program}

The mean score of all components and factors of perceived changes in residential camps with 3 or more sessions of adventure activities were not significantly different from the day camps with less than three sessions of adventure activities. Details of the findings, which were listed in Table 18 and Table 19, were as below:

(a) The mean participant's characteristics score of residential camps $(\mathrm{M}=3.86, \mathrm{SD}=1.50)$ was not significantly different $(\mathrm{t}=0.81$, $\mathrm{df}=337$, two-tailed $\mathrm{p}=0.420)$ from day camps $(\mathrm{M}=3.71, \mathrm{SD}=1.67)$.

(b) The mean physical environment score of residential camps $(\mathrm{M}=4.28, \mathrm{SD}=1.33)$ was not significantly different $(\mathrm{t}=1.51$, df $=337$, two-tailed $\mathrm{p}=0.132)$ from day camps $(\mathrm{M}=4.03, \mathrm{SD}=1.61)$.

(c) The mean social environment score of residential camps $(\mathrm{M}=4.58, \mathrm{SD}=1.42)$ was not significantly different $(\mathrm{t}=0.33$, df $=335$, two-tailed $\mathrm{p}=0.744)$ from day camps $(\mathrm{M}=4.52, \mathrm{SD}=1.53)$. (d) The mean program activities score of residential camps $(\mathrm{M}=4.30, \mathrm{SD}=1.51)$ was not significantly different $(\mathrm{t}=0.51, \mathrm{df}=337$, two-tailed $\mathrm{p}=0.960)$ from day camps $(\mathrm{M}=4.29, \mathrm{SD}=1.72)$.

(e) The mean instructors score of residential camps ( $\mathrm{M}=$ $4.50, \mathrm{SD}=1.48)$ was not significantly different $(\mathrm{t}=$ 1.32, df $=337$, two-tailed $p=0.188)$ from day camps $(\mathrm{M}=4.26, \mathrm{SD}=1.73)$.

(f) The mean mastery score of residential camps ( $\mathrm{M}=$ $4.60, \mathrm{SD}=1.44)$ was not significantly different $(\mathrm{t}=$ -1.16 , df $=337$, two-tailed $p=0.249$ ) from day camps $(\mathrm{M}=4.79, \mathrm{SD}=1.36)$.

(g) The mean reflection score of residential camps ( $\mathrm{M}=$ $4.50, \mathrm{SD}=1.52)$ was not significantly different $(\mathrm{t}=$ -0.35 , df $=336$, two-tailed $\mathrm{p}=0.725)$ from day camps $(\mathrm{M}=4.56, \mathrm{SD}=1.68)$. 
Table 18. Means and Standard Deviations of Seven Adventure Components/Factors by Length of Adventure Programs.

\begin{tabular}{lllll}
\hline & Activity Session & N & Mean & Std. Deviation \\
\hline Participant's Characteristics & $>=3$ & 235 & 3.86 & 1.50 \\
& $<3$ & 104 & 3.71 & 1.67 \\
Physical Environment & $>=3$ & 235 & 4.28 & 1.32 \\
& $<3$ & 104 & 4.03 & 1.61 \\
Social Environment & $>=3$ & 233 & 4.58 & 1.41 \\
& $<3$ & 104 & 4.52 & 1.53 \\
Program Activities & $>=3$ & 235 & 4.30 & 1.50 \\
& $<3$ & 104 & 4.29 & 1.72 \\
Instructors & $>=3$ & 235 & 4.50 & 1.48 \\
& $<3$ & 104 & 4.26 & 1.72 \\
Mastery & $>=3$ & 235 & 4.60 & 1.44 \\
\multirow{3}{*}{ Reflection } & $<3$ & 104 & 4.79 & 1.35 \\
& $>=3$ & 235 & 4.50 & 1.51 \\
& $<3$ & 103 & 4.56 & 1.67 \\
\hline
\end{tabular}

Table 19. Unrelated t-test Output between Length of adventure Programs and Seven Adventure Components/ Factors.

\begin{tabular}{|c|c|c|c|c|c|c|}
\hline \multicolumn{4}{|c|}{$\begin{array}{l}\text { Levene's Test for } \\
\text { Equality of Variances }\end{array}$} & \multicolumn{3}{|c|}{ t-test for Equality of Means } \\
\hline & & F & $\mathrm{p}$ & $\mathrm{t}$ & df & $\mathrm{p}$ \\
\hline \multirow[t]{2}{*}{ Participant's Characteristics } & Equal variances assumed & 3.365 & .067 & .808 & 337 & .420 \\
\hline & Equal variances not assumed & & & .776 & 179.846 & .439 \\
\hline \multirow[t]{2}{*}{ Physical Environment } & Equal variances assumed & 2.487 & .116 & 1.508 & 337 & .132 \\
\hline & Equal variances not assumed & & & 1.400 & 167.500 & .163 \\
\hline \multirow[t]{2}{*}{ Social Environment } & Equal variances assumed & .484 & .487 & .326 & 335 & .744 \\
\hline & Equal variances not assumed & & & .316 & 184.498 & .752 \\
\hline \multirow[t]{2}{*}{ Program Activities } & Equal variances assumed & 2.983 & .085 & .051 & 337 & .960 \\
\hline & Equal variances not assumed & & & .048 & 175.748 & .962 \\
\hline \multirow[t]{2}{*}{ Instructors } & Equal variances assumed & 1.818 & .178 & 1.319 & 337 & .188 \\
\hline & Equal variances not assumed & & & 1.243 & 172.647 & .216 \\
\hline \multirow[t]{2}{*}{ Mastery } & Equal variances assumed & .644 & .423 & -1.155 & 337 & .249 \\
\hline & Equal variances not assumed & & & -1.183 & 208.895 & .238 \\
\hline \multirow[t]{2}{*}{ Reflection } & Equal variances assumed & .947 & .331 & -.352 & 336 & .725 \\
\hline & Equal variances not assumed & & & -.338 & 178.197 & .735 \\
\hline
\end{tabular}




\section{Discussions}

In the past, the Children and Youth Division of the Hong Kong Council of Social Service was responsible for the coordination of camps and hostels service of voluntary agencies in Hong Kong. The Camps and Hostels Service was operated to provide children and youth with opportunities to widen their perspectives, to share group life, and to develop their potential through the appreciation of nature and social life. By means of a variety of outdoor activities, the idea of healthy use of leisure was promoted. It also provided a place for relaxation for adults who may be heavily pressed by their daily workload. Indeed, leisure and recreation have already become an indispensable part of modern city life. In the year 1983-84, a total of 21,757 camping groups, with a total attendance of 850,289, were recorded (Hong Kong Council of Social Service, 1985). Furthermore, there were 66 nonprofit making camps and hostels in 1985.

The first outdoor recreation camp for children in Hong Kong, according to the information in the website of Hong Kong Playground Association, was built in 1951 in Lantau Island at Tung Tau Wan and was officially opened by ex-Hong Kong Governor Mr. Grantham on 23 December 1952. Hong Kong Rotary Club (香港扶輪社) donated \$100,000 for the construction of camp site. Facilities in the camp site were donated by Hong Kong Football Association (香港足 球總會) and Chinese Charity Fund Committee (華人慈善基 金會). The camp was named as Silvermine Bay Children Camp (銀磺灣兒童營) and mainly served the children of lowincome families from the Social Welfare Department and children clubs in Boys' and Girls' Club Association of Hong Kong. The camp was first managed by the Management Committee on Camps (營地管理委員會) and the management was handled over to Hong Kong Playground Association in March 1966 and its services were to provide chances for children of lowincome families to enjoy outdoor camping life and to develop their personalities.

In summer holidays of early 1970, Recreation and Sports Services of the Education Department started using the vacant Leung Shuen Wan Public School and Ko Lau Wan Public School to organize summer camps for children and youths in Hong Kong. This was the first of its kind organized by the Hong Kong Government.

The first Government camp site with residential camp places was Sai Kung Outdoor Recreation Centre at Tui Min Hoi Area, Sai Kung. The Centre was a barrack before it was re-developed as a camp site. It has provided residential camp and day camp services to the public since May 1976. The major aims and objectives of operating camps by Hong Kong Government were (a) to provide an opportunity for members of the public, who might not otherwise have the opportunity, to escape from the rigors of daily life and enjoy a few peaceful healthy and inexpensive days in a rural environment and (b) to contribute towards community building by encouraging people to plan their leisure time and take part in organized programmes.

After the establishment of Leisure and Cultural Services Department in 2000, all subventions of non-government organization camps were under the control of Camps Unit of Leisure and Cultural Services Department. At the moment, there are totally 57 camps and hostels in Hong Kong, including five LCSD camps, namely, Tso Kung Tam Outdoor Recreation Centre in Tsuen Wan, Lei Yue Mun Park and Holiday Village in Chai Wan, Sai Kung Outdoor Recreation Centres, Lady MacLehose Holiday Village and Chong Hing Water Sports Centre (with tent camp site only) in Sai Kung and seven youth hostels that provided accommodation only.

Limited adventures programs and facilities were started providing in Government camps in recent years. An adventure area in Tso Kung Tam Outdoor Recreation Centre with a Spider Web, T.P. Shuffle, Islands and V Bridge was just completed in October 2005 and open for public use recently. However, organizations must have or hire their own instructors or facilitators while using the facilities. Roles in using adventure facilities and promoting adventure programs in Government camps are passive and low keyed while comparing with their non-profit counterparts.

Major findings of the present studies which were elaborated in the previous section can be summarized as follows:

(a) Nine out of eleven Hattie et al's domains of self-concept (except physical appearance at $\mathrm{M}=3.27$ and family at 2.81) were scored with mean values higher than 3.5 and were classified as having certain degree of perceived effects on respondents. The nine domains, in the descending order, were peer relationship, confidence, self-understanding, well-being, independence, self-problem solving, selfefficacy, general self, and physical ability.

(b) The mean scores of ten out of eleven domains (except confidence) from male participants were not significantly different from female participants. 
(c) The mean scores of physical ability, confidence, family and self-understanding of participants aged 18 and above were not significantly different from participants aged below 18. However, the mean scores of peer relationship, general self, physical appearance, self-problem solving, self-efficacy, well being and independence of participant aged 18 and above were significantly higher than participants aged below 18 .

(d) The mean scores of ten out of eleven domains (except independence ) of participants attended residential camps with 3 or more sessions of adventure activities was not significantly different from day camps with less than 3 sessions of adventure activities.

(e) All listed Golin and Walsh factors/components scored mean scores were higher than 3.5 and were classified as perceived factors/components contributed to the change, i.e. mastery, reflection, social environment, instructors, program activities physical environment and participant's characteristics.

(f) The mean scores of all factors and components of perceived change of male participants were not significantly different from female participants.

(g) The mean scores of all factors and components of perceived changes of participants aged 18 and over were significantly higher than participants aged below 18

(h) The mean score of all factors and components of perceived changes in residential camps with 3 or more sessions of adventure activities were not significantly different from the day camps with less than three sessions of adventure activities.

Although nine out eleven Hattie et al's domains were over 3.5 , their means ranged from 3.71 to 4.76 only. In other words, respondents only suggested that they slight agreed their perceived, peer relationship, confidence, self-understanding, well-being, independence, self-problem solving and self-efficacy domains (in the descending order) were improved after participating in camp adventure programs. Hattie et al (1997) concluded that the greatest effects of the adventure programs in the self-concept domain were for independence, confidence, selfefficacy and self-understanding; however, the effects on peers were typically smaller. Perhaps, the difference between Hattie et al's findings and this study was due to the programs in Hattie et al's meta-analysis lasted from 1 and 120 days, with a mean of 24 days (SD = 16) and seventy-two percent of the programs were between 20 and 26 days in length. The programs in the present study only lasted for a 1 to 3 -hour session to 12 sessions of adventure programs in a 5 days 4 nights residential camp and $54.6 \%$ respondents joined a 3 days 2 nights residential camps. The choice of adventure programs may be another reason. To reduce the potential risk of the camp adventure programs, large amount of counseling and trust activities were included in local camp adventure programs. Such programs offered in the local camps will probably be varied from those in the western cultures, and in turn which may affect the outcome of the present investigation.

No difference was found between male participants and female participants in perceiving a certain degree of change in ten out of eleven domains (except confidence). Such findings were same as other researches in the field to a great extent. In other words, perceived effects of camp adventure programs on both male participants and female participants were the same in most of the domains of self-concept. Anyway, unless the purpose of the programs was mainly to enhance confidence, special attention seemed to be unnecessary for different genders while camp administrators designed their camp adventure programs.

Results on various aspects of self-concept were contradictory between participants aged 18 and above and participants aged below 18. Such findings also contradicted to many studies in the field which indicated no effect of camping and adventure programs as a result of age. Such aspect should be explored in more details in future study. Anyway, as the perceived effects on some domains of self-concept were different between adults, i.e. participants aged 18 and over, and teenagers aged 12-17, the camp management should pay attention to the design of camp adventure programs while the targets of their programs were different.

Length of camp adventure programs had no significant effect on the perceived change in ten out of eleven domains (except independence). Perhaps, the components and factors were more important than length of programs in contributing to perceived change in self-concept.

The present findings indicated that respondents considered all seven factors and components contributed to their perceived change. Participant's characteristic was the factor that gained the minimum score whereas mastery got the highest mean scores at 4.65 among the remaining factors. Such findings implied that camp management should pay special efforts to 
enhance these factors and components in order to improve the camp adventures programs. Results also indicated that there were no significant difference in perceived components and factors due to the difference of age, gender and length of camp adventure programs. Again, such findings could be taken as a reference for camp management in planning future adventure programs.

Although factor analysis on domains of self-concept with perceived change and factor analysis on components/factors perceived to be causes of changes were conducted, components or latent roots cannot be identified in both factor analysis. Some possible reasons might be due to such cultural differences in subjects' perception or the background physical abilities. It indicated that respondents attending camp adventure programs perceived certain degree of change in various domains of self-concept.

In fact, all seven components/factors in alternate Walsh and Golins' model of Outward Bound Process suggested by McKenzie (2003) are worth paying attention to while camps organize camp adventure programs. Parents want their children to have whatever it takes to be happy and successful - good health, ability to get along with others, thinking and problemsolving skills, and a good self-concept. Throughout the youth development, they need resiliency skills: self-esteem, life skills, self-reliance and pro-social behaviors. The camp experience should offer a nurturing environment away from the distractions and hostile environment to acquire these skills. Dr. Peter Scales (cited in Coutellier, 2004), senior fellow at The Search Institute said, "The biggest plus of camp is the camps help young people discover and explore their talents, interests, and values. Kids who have had these kinds of camp experiences end up being healthier and have fewer problems which concern us all." (p.8). A well-conducted camp should provide educational, social and recreational experiences vital to the growth and development of campers, especially youth ones.

\section{References}

Attarian, A. (1991). Research on adventure (risk) recreation. Parks \& Recreation, 5, 19-23; 65.

Cason, D., \& Gillis, H.L. (1994). A meta-analysis of outdoor adventure programming with adolescents. The Journal of Experiential Education, 17, 40-47.

Coutellier, C. (2004). Day camp from day one: a handon guide for day camp administrators. United States of America: American Camping Association.

Cross, R. (2002). The effects of an adventure education program on perceptions of alienation and personal control among at-risk adolescents. Journal of Experiential Education, 25(1), 247-254.

Csikzentmihalyi, M. (1990). Flow : the psychology of optimal experience. New York: Harper \& Row.

Delansky, B. (1991). Outcomes of organized camping a review of research literature. Retrieved Oct 18, 2005 from http://www.acacamps.org/research/delansky.pdf

Duquin, M. (2000). Sport and emotions. In J. Coakley, \& E. Dunning (Eds). Handbook of sports studies (pp. 477 - 489). London: SAGE.

Ewert, A. (1983). Outdoor adventure and self-concept : A research analysis. Eugene, OR: University of Oregon, Center of Leisure Studies.

Ewert, A. (1989). Outward adventure pursuits: foundations, models and theories. Ohio, $\mathrm{OH}$ : Publishing Horizons.

Ford, P., \& Blanchard. J. (1993). Leadership and administration of outdoor pursuits. Pennsylvania, PA: Venture.

Freischiag, J., \& Freischiag, T. (1993). Selected psycho-social, physical and technical factors among rock climbers; A test of the flow paradigm. Applied Research in Coaching and Athletics Annual. 4, 109-122.

Garst, G., Scheider, I., \& Baker, D. (2001). Outdoor adventure program participation impacts on adolescent self-perception. Journal of Experiential Education, 24(1), 41-49. 
Gass, M., Garvey, D., \& Sugerman, D. (2003). The longterm effects of a first-year student wildness orientation program. Journal of Experiential Education, 26(1), 3440.

Glass, G.V., McGaw, B., \& Smith, M.L. (1981). Meta-analysis in social research. Beverly Hills, CA: Sage.

Goldenberg, M.A., Klenosky, D.B., O'Leary, J. T., \& Templin, T.J. (2000). A means-end investigation ropes course experiences. Journal of Leisure Research. 42, (2), 208224.

Hahn, K. (1957). Outward bound. New York: World Books.

Hattie, J., Marsh, H., Neill, J., \& Richards, G. (1997). Adventure education and outward bound: out-of-class experiences that make a lasting difference. Review of Educational Research, 67(1), 43-87.

Hedges, L.V., \& Olkin, I. (1985). Statistical methods for metaanalysis. New York : Academic.

Holman, T. (2003). Outcomes-consequences-values of an integrated wilderness adventure program. Journal of experiential Education, 25(3), 353-354.

Hopkins, D. (1982). Changes in self concept as a result of adventure training. CAPHER Journal, 48(6), 9-12.

Hopkins, D., \& Putnam, R. (1998). Personal growth through adventure. London: David Fulton.

Leiweke, J.T. (1976). The influence of the twenty-four day Outward Bound experience on self-actualization (Doctoral dissertation, Saint Louis University). Dissertation Abstracts International, 37, 3523A

Lewicki, R.J. (1977). Outward Bound sensitivity training : Experiential learning in the wild. Hanover, NH : Amos Tuck School of Business Administration. Dartmouth College.

Lowenstein, D. (1975). Wilderness adventure programs : An activity profile. Unpublished technical report, Pennsylvania State University. (ERIC Document Reproduction Service No. ED 127 102)
March, H.W., \& Richard, G.E. (1986). The Rotter locus of control scale : The comparison of alternative response formats and implications for reliability, validity, and dimensionality. Journal of Research in Personality, 20, 509-528.

Marsh, H.W., \& Peart, N.D. (1988). Competitive and cooperative physical fitness training programs for girls : Effects on fitness and on multidimensional self-concepts. Journal of Sports Psychology, 10, 390-407.

Matthai, R.A. (1973). The effect of Outward Bound on sense of competence (Doctoral dissertation, Harvard University). Dissertation Abstracts International, 34, 7050A.

McKenzie, M. (2003). Beyond ìthe outward bound processî rethinking student learning. Journal of Experiential Education, 26(1), 8-23.

Miner, J., \& Boldt, J. (1981). Outward Bound USA : Learning through experience in adventure-based education. New York: William Morrow.

Neuman, W.L. (2003). Social research methods: qualitative and quantitative approaches (5 $5^{\text {th }}$ ed.) Boston: Allyn and Bacon.

Nold, J. (1976). Growth and crises in a developing organization. Denver, CO: Outward Bound School.

Parle, M.D. (1986). The role of self-efficacy in Outward Bound : An investigation of a high school course. Unpublished bachelor's honors dissertation, University of New England, Armidale, New South Wales, Australia.

Rossman, J.R., \& Schlatter, B. E. (2000). Recreation programming. Champaign, IL: Sagamore

Russell, K. (2000). Exploring how the wilderness therapy process relates to outcomes. Journal of Experiential Education, 23(3), 170-6.

Scherl, L.A., \& Smithson, M. (1986, May). A new dimension to content analysis : Exploring relationships among thematic categories. Paper presented at the $15^{\text {th }}$ Annual Meeting of the Australian Social Psychologists, Magnet Island, Queensland, Australia. 
Schoel, J., Prouty, D., \& Radcliffe, P. (1988). Island of healing: a guide to adventure based counseling. Project Adventure.

Shavelson, R., Hubner, J., \& Stanton, G.C. (1976). Self-concept : Validation of construct interpretations. Review of Educational Research, 46, 407-441.

Shivers, J. S. (1989). Camping organization and operation. New Jersey: Prentice Hall.

Sibthorp, J. (2003). An empirical look at Walsh and Golins adventure education process model: relationship between antecedent factors, perceptions of characteristics of an adventure experience and self-efficacy. Journal of Leisure Research, 35(1), 80-106.

Walsh, V., \& Golins, G. (1976). The exploration of the Outward Bound process. Denver, CO: Colorado Outward Bound School.

Wetmore, R.C. (1972). The influence of Outward Bound school experience on the self-concept of adolescent boys (Doctoral dissertation, Boston University). Dissertation Abstracts International, 33, 1498A.

Wilson, R. (1981). Inside Outward Bound. Charlotte, NC : East Wood.

Youth Section of the Social Welfare Department (2004). Understanding the adolescent project. [Brochure] Hong Kong Special Administration Region Government.

Youth Section of the Social Welfare Department (2003). Brief on report on evaluation of the understanding the adolescent project (UAP) in secondary school 2001/02. Retrieved October 10, 2004 from http://www.info.gov.hk/swd/html_tc/ ser_sec_ser_young.

Youth Section of the Social Welfare Department. (2003). Understanding the adolescent project: users' manual. Hong Kong Special Administrative Region Government.

香港兒童及青少年服務概. Retrieved on October 15, 2004 from http://www.hkcss.org.hk/cy/Profile of CY.doc

青少年服務， Retrieved on October 15，2004 from http://www.info.gov.hk/swd/text_chi/ser_sec/ser_young/ indexhtml
徐漢明，陳國榮，陳國邦 (編輯). (2002). 歷奇為本輔導概 念與實踐。香港:香港小童群益會.

香港社會服務聯會兒童及青年部營舍服務協調委員會(編輯). (1985)，香港營舍冊。香港：香港社會服務聯會.

李德誠，麥淑華（2002)，整全的歷奇輔導，香港：突破.

營舍服務歷史. Retrieved on November 11, 2005 from http://www.hkpacamp.com/history.php?995/

\section{Correspondence:}

Dr. Lobo Louie

Department of Physical Education, Hong Kong Baptist University, Kowloon Tong, Hong Kong. Email: s62591@hkbu.edu.hk 